Article

\title{
Synthesis of Tyrosol and Hydroxytyrosol Glycofuranosides and Their Biochemical and Biological Activities in Cell-Free and Cellular Assays
}

\author{
Peter Kis ${ }^{1}$, Eva Horváthová ${ }^{2}$, Eliška Gálová ${ }^{3}$, Andrea Ševčovičová $^{3}{ }^{\mathbb{D}}$, Veronika Antalová ${ }^{3}$, \\ Elena Karnišová Potocká ${ }^{1}$, Vladimír Mastihuba ${ }^{1}$ and Mária Mastihubová ${ }^{1, *(1)}$ \\ 1 Institute of Chemistry, Slovak Academy of Sciences, 84538 Bratislava, Slovakia; peter.kis@savba.sk (P.K.); \\ elena.potocka@savba.sk (E.K.P.); vladimir.mastihuba@savba.sk (V.M.) \\ 2 Cancer Research Institute, Biomedical Research Center, Slovak Academy of Sciences, \\ 84505 Bratislava, Slovakia; eva.horvathova@savba.sk \\ 3 Department of Genetics, Faculty of Natural Sciences, Comenius University, 84215 Bratislava, Slovakia; \\ eliska.galova@uniba.sk (E.G.); andrea.sevcovicova@uniba.sk (A.Š.); veron.antalova@gmail.com (V.A.) \\ * Correspondence: maria.mastihubova@savba.sk; Tel.: +421-2-59410655
}

Citation: Kis, P.; Horváthová, E.; Gálová, E.; Ševčovičová, A.; Antalová, V.; Karnišová Potocká, E.; Mastihuba, V.; Mastihubová, M. Synthesis of Tyrosol and Hydroxytyrosol Glycofuranosides and Their Biochemical and Biological Activities in Cell-Free and Cellular Assays. Molecules 2021, 26, 7607. https:// doi.org/10.3390/molecules26247607

Academic Editors: Bruno Botta, Cinzia Ingallina, Andrea Calcaterra and Deborah Quaglio

Received: 18 November 2021 Accepted: 13 December 2021 Published: 15 December 2021

Publisher's Note: MDPI stays neutral with regard to jurisdictional claims in published maps and institutional affiliations.

Copyright: (c) 2021 by the authors. Licensee MDPI, Basel, Switzerland. This article is an open access article distributed under the terms and conditions of the Creative Commons Attribution (CC BY) license (https:// creativecommons.org/licenses/by/ $4.0 /)$.

\begin{abstract}
Tyrosol (T) and hydroxytyrosol (HOT) and their glycosides are promising candidates for applications in functional food products or in complementary therapy. A series of phenylethanoid glycofuranosides (PEGFs) were synthesized to compare some of their biochemical and biological activities with $\mathrm{T}$ and HOT. The optimization of glycosylation promoted by environmentally benign basic zinc carbonate was performed to prepare HOT $\alpha$-L-arabino-, $\beta$-D-apio-, and $\beta$-D-ribofuranosides. T and HOT $\beta$-D-fructofuranosides, prepared by enzymatic transfructosylation of $\mathrm{T}$ and HOT, were also included in the comparative study. The antioxidant capacity and DNA-protective potential of T, HOT, and PEGFs on plasmid DNA were determined using cell-free assays. The DNA-damaging potential of the studied compounds for human hepatoma HepG2 cells and their DNA-protective potential on HepG2 cells against hydrogen peroxide were evaluated using the comet assay. Experiments revealed a spectrum of different activities of the studied compounds. HOT and HOT $\beta$-D-fructofuranoside appear to be the best-performing scavengers and protectants of plasmid DNA and HepG2 cells. T and $\mathrm{T} \beta$-D-fructofuranoside display almost zero or low scavenging/antioxidant activity and protective effects on plasmid DNA or HepG2 cells. The results imply that especially HOT $\beta$-D-fructofuranoside and $\beta$-D-apiofuranoside could be considered as prospective molecules for the subsequent design of supplements with potential in food and health protection.
\end{abstract}

Keywords: tyrosol; hydroxytyrosol; phenylethanoid glycofuranosides; basic zinc carbonate; antioxidant activity; cytotoxicity; DNA damage; DNA-protective effect

\section{Introduction}

Epidemiological studies indicate that plant-derived foods exert some beneficial effects on human health [1], particularly on age-related diseases [2]. Phenylethanoid antioxidants tyrosol (1, T) and hydroxytyrosol (2, HOT) (Figure 1) are relatively broadly spread in nature and are intensively studied for such properties [3,4]. They constitute structural parts of natural compounds such as ligustroside (3a), oleuropein (3b), and phenylethanoid glycosides (PEGs) [5-9]. While the sources of $\mathbf{3 a}$ and $\mathbf{3 b}$ are agroindustrial by-products from olive mills [10], PEGs have been found in various plant-based foods, such as edible flowers and tea [8]. Moreover, PEG acteoside (also known as verbascoside, 4a) has been found in olive tree by-products, alongside T, HOT, and $\mathbf{3 a}$ and $\mathbf{3 b}$ [10,11] (Figure 1). Olive metabolites $\mathbf{2}, \mathbf{3 b}$, and $\mathbf{4} \mathbf{a}$ appear to act as topoisomerase II poisons in complex preparations intended for human consumption [12]. 
<smiles>OCCc1ccc(O)cc1</smiles>

3a: $\mathrm{R}=\mathrm{H}$<smiles>OCCc1ccc(O)c(O)c1</smiles>

2 (HOT)

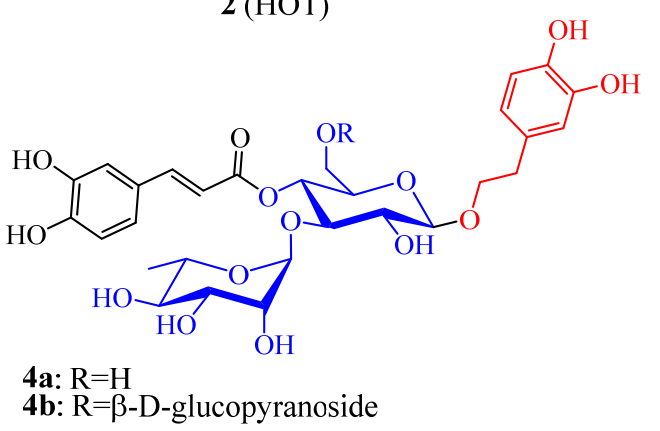

Figure 1. Representatives of phenylethanoids isolated from olive tree by-products or medicinal plants.

Nowadays, there is growing scientific interest focused on HOT, which is a promising candidate for application in functional food products or in complementary therapy. HOT is by far the most investigated olive polyphenol, possibly not only due to its antioxidant power [13] and tasteless character, but also because it is a product of oleuropein 3a degradation. It can be found in high concentrations in olive oil mill wastewater, produced during mechanical olive processing within olive oil production [14]. A wide variety of health-beneficial effects attributable especially to HOT and their potential therapeutic applications were recently reviewed [15-17]. Further reviews focused on mapping its high antioxidant capacity and important anti-inflammatory, anticancer, cardioprotective, and neuroprotective effects [18-20]. HOT was recently approved as a novel safe food additive [21], and there is an increasing number of papers on its large-scale isolation from natural resources [14] or chemical and biotechnological production $[18,22,23]$ due to the interest of the food, feed, supplementary, and pharmaceutical sectors.

The unsubstituted HOT is, however, rather unstable and has other shortcomings. For example, the rapid metabolism of HOT leads to the low bioavailability of the active substance and the bioavailability depends to a large extent on the vehicle in which HOT is administered [24-26]. HOT was found to be a potent $\mathrm{OH}^{\bullet}, \mathrm{O}_{2}{ }^{\bullet-}$, and $\mathrm{ONOOH}$ scavenger but a poor scavenger of $\mathrm{HOCl}$ and $\mathrm{H}_{2} \mathrm{O}_{2}$ [13]. Tailored functionalization of natural phenols can upgrade their properties $[27,28]$. The chemical modification of HOT can help to improve their characteristics, such as chemical stability, solubility, and bioavailability, or to increase the antioxidant or biological activity by altering the pharmacokinetic profile. Natural diphenols are often used as scaffolds to prepare new, effective biologically active drugs. There have been developed synthetic strategies to broaden the applications of HOT in foodstuffs, cosmetics, and pharmaceuticals [29,30].

One of the possibilities to extend the applications of HOT is glycosylation of its primary $\mathrm{OH}$ group without impacting the catechol moiety in order to preserve the antioxidant properties. The use of carbohydrates as scaffolds or pharmacophores in the field of polyphenolic compounds can result in a variety of structures with different spatial arrangements, reactivity to enzymes, or the ability to bind to cellular receptors. Structurally, this type of glycophenolic occurs in a large group of natural bioactive substances: PEGs. PEGs are water-soluble compounds widely distributed in medicinal plants. They are characterized by a hydroxyphenylethyl moiety (mostly HOT) attached to $\beta$ - $D$-glucopyranose (rarely $\beta$-D-allopyranose) through 1,2-trans glycosidic linkage. The central glucopyranoside may be decorated by a hydroxyphenylpropenoyl moiety and/or other monosaccharides [5-9]. Acteoside $4 \mathbf{a}$ and echinacoside $\mathbf{4 b}$ (which is a constituent of various nutritional supplements from Echinacea purpurea), depicted in Figure 1, are some of the best-known representatives of PEGs.

Chemical preparation of $\mathrm{T}$ or HOT glycosides usually requires several steps of synthesis. In general, T or HOT protected on the phenolic groups is glycosylated by a protected activated glycosyl donor and the product is ultimately deprotected [31,32]. The weak point 
of such synthesis may be the insufficient stereoselectivity of the glycosylation and the eventual purification of the mixture of anomers [33]. The controlled regioselective attachment of additional monosaccharides and/or a phenylpropanoid moiety to the molecules requires the application of a sophisticated synthetic strategy [34,35]. Direct glycosylation of T or HOT is possible by a selective enzyme transglycosylation of suitable glycosyl donor [35-43]. Some glycosidases, however, do not distinguish between the phenolic hydroxyl and the primary hydroxyl of phenylethanoid acceptors [44,45].

Glycofuranosides [46,47] are widely spread in nature, oftentimes in the form of oligoor polysaccharides. While D-fructofuranosides [48], L-arabinofuranosides [49], and Dapiofuranosides [50] are found in plants, D-galactofuranosides and D-arabinofuranosides are present in microorganisms [51]. In addition, D-ribofuranosides and 2-deoxy-Dribofuranosides are essential in nucleic acids. Glycofuranosyl-containing conjugates may have different biological or physicochemical properties than analogous glycopyranosides. They are recognized in plants and microorganisms by different enzymes [52-56]. Nondigestible plant fructooligosaccharides and arabinoxylans have prebiotic effects [57].

To the best of our knowledge, T or HOT glycofuranosides have not yet been isolated from nature, but the existence of other natural furanosyl-containing polyphenols is known. For example, myricetin-3-O- $\alpha$-L-arabinofuranoside isolated from Calycolpus warszewiczianus displays weak antimalarial activity [58] or (-)-catechin-7-O- $\beta$-D-apiofuranoside from Ulmus davidiana var. japonica inhibits hepatic stellate cell activation [59]. As a result, structurally well-defined synthetic furanosyl analogs of PEGs are of great interest for their potential therapeutic applications.

Our laboratory has experience in the preparation of phenolic arylalkyl glycosides by conventional chemical synthesis $[32,33,60]$ as well as enzymatic transglycosylation [38-40,61]. As a part of our research program directed toward PEGs, we have recently synthesized a series of natural and unnatural phenylethanoid glycopyranosides (PEGPs). Then, we evaluated their antioxidant properties (reducing power, DPPH radical scavenging, and $\mathrm{Fe}^{2+}$-chelating activity) as well as DNA-protective potential using cell-free approaches as well as an experimental system using in vitro cultured human cells. The PEGPs cytotoxicity on human hepatoma HepG2 cells (MTT test) and the protective potential against lesions induced by a model DNA-damaging agent $\left(\mathrm{H}_{2} \mathrm{O}_{2}\right.$; comet assay) were assessed. While hydroxysalidroside proved to be the best candidate in cell-free experiments, salidroside was effective in protection at the cellular level at all tested concentrations [32].

In this work, we intended to prepare HOT glycofuranosides ( $\alpha$-L-arabino-, $\beta$-D-apio-, and $\beta$-D-ribofuranoside) as analogues to HOT glycopyranosides and to investigate their potential in the same biochemical and biological in vitro experiments. At the same time, we wanted to compare the potential of aglycones (T, HOT) as well as previously enzymatically prepared $\beta$-D-fructofuranosides [39].

\section{Results and Discussion}

\subsection{Synthesis of Hydroxytyrosol Glycofuranosides}

$\mathrm{T}$ and HOT $\beta$-D-fructofuranosides $\mathbf{5} \mathbf{a}$ and $\mathbf{5 b}$ (TYBFRU and HOTFRU) (Figure 2) were prepared from sucrose by enzymatic transfructosylation catalyzed by yeast $\beta$-galactosidase Lactozym $3000 \mathrm{~L}$ comprising invertase activity [39]. Generally, the chemical synthesis of $\beta$-fructofuranosides is difficult due to the cis-position of the OH group on C-3 with the aglycone on C-2 in $\beta$-D-fructofuranosides. The possibility of efficient preparation of $\mathbf{5 a}$ and $\mathbf{5 b}$ with invertase with high synthetic activity was, therefore, an advantage. When structurally different glycosides are to be prepared, enzymatic glycosylation is complicated by the need of appropriate enzyme with suitable substrate specificity. Recently, the possibility of enzymatic preparation of $\beta$-D-apiosides (3-C branched D-erythrofuranosides) was investigated in our laboratory, but no enzyme with a transapiosylating activity was found, since all tested apiosidases were able to catalyze only apioside hydrolysis $[62,63]$. We, therefore, decided to study suitable conditions for chemically promoted 1,2-trans-glycofuranosylation and to 
prepare HOT $\alpha$-L-arabinofuranoside (6, HOTARA), HOT $\beta$-D-apiofuranoside (7, HOTAPI), and HOT $\beta$-D-ribofuranoside (8, HOTRIB) in this way (Figure 2).

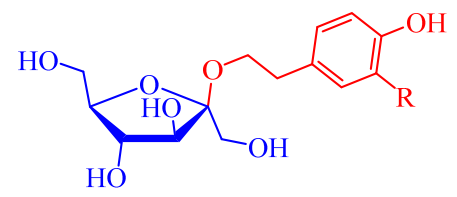

5a (TYBFRU) $\mathbf{5 b}$ (HOTFRU)

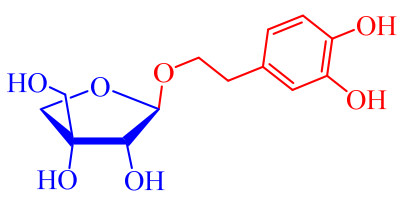

7 (HOTAPI)<smiles>OC[C@H]1O[C@H]2O[C@H](CO)[C@H](O2)[C@@H]1O</smiles>

6 (HOTARA)<smiles>OCC1O[C@@H]2OCCc3ccc(O)c(O)c3C=C2[C@H]1O</smiles>

8 (HOTRIB)

Figure 2. Overview of prepared and tested PEGFs.

We decided to build on our previous work [33], in which we studied environmentally friendly methods of the modified Koenigs-Knorr glycosylation using zinc oxide ( $\mathrm{ZnO})$ or basic zinc carbonate $\left(\left[\mathrm{ZnCO}_{3}\right]_{2} \cdot\left[\mathrm{Zn}(\mathrm{OH})_{2}\right]_{3}\right)$ as a promoter. These inexpensive and environmentally benign $\mathrm{Zn}$ (II) promoters have been found to be efficient and selective for 1,2-trans-glucosylation of tyrosol and hydroxytyrosol with the phenolic hydroxyls protected by easily removable acetyl or $t$-butyldimethylsilyl groups. Various per-O-acetylated hexopyranosyl, pentopyranosyl, and rungiosyl bromides have been successfully used to determine the viability and scope of this method [33]. For this study, we chose a more stereoselective glycosylation method promoted by basic zinc carbonate. Similarly to the synthesis of analogous pyranosides, the standard procedure for preparing 1,2-trans-furanosides uses glycosyl donors that have acyl protecting groups at O-2 $[64,65]$.

To ensure the furanose form of the products $6-8$, it was important to prepare starting per-O-acylated furanoses 9-11 (Scheme 1). 1,2,3,5-Tetra-O-acetyl- $\alpha, \beta$-L-arabinofuranose (9) was prepared in a three-step synthesis according to Backinowski et al. from L-arabinose [66]. The pentofuranose 9 was obtained as an anomeric mixture with anomer composition $\alpha: \beta=3: 1$. 5-O-Benzoyl-1,2,3-tri-O-acetyl- $\alpha, \beta$-D-apiofuranose (10) $(\alpha: \beta=1: 4)$ was obtained from 2,3-O-isopropylidene- $\alpha, \beta$-D-apiofuranose by enzymatic benzoylation, acid-catalyzed deisopropylidenation, and acetylation [62]. The starting 2,3-isopropylidenated D-apiofuranose was obtained from D-mannose in several steps $[67,68]$. Per-O-acetyl- $\alpha, \beta$-D-ribofuranose $11(\alpha: \beta=1: 2.5)$ was synthesized in a similar manner to the synthesis of peracetyl-Darabinofuranose 9 by the Guthrie-Smith method [69]. The kinetic product methyl Dribofuranoside obtained by acidic methanolysis was acetylated, followed by acetolysis of the methyl group. Aglycone 12 (HOT protected on phenolic moieties by acetylation) was prepared from the corresponding hydroxyphenylacetic acid by a two-step sequence: protection of phenolic groups and reduction of the carboxyl group [33]. 


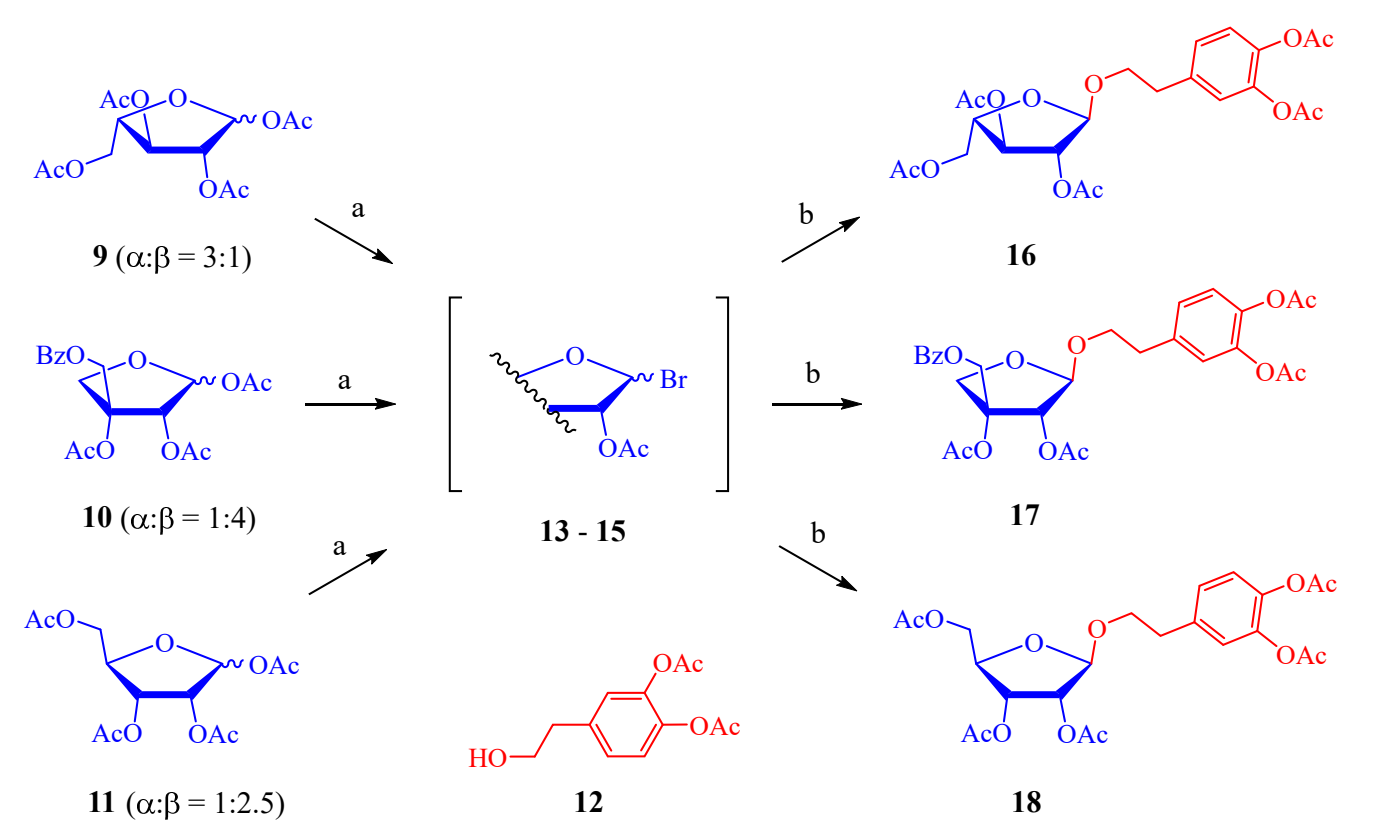

Scheme 1. Glycofuranosylation of protected HOT 12. Reagents and conditions: (a) TMSBr (5.0 equiv), $\mathrm{CH}_{2} \mathrm{Cl}_{2}, 4{ }^{\circ} \mathrm{C}$-rt, $4-15 \mathrm{~h}, \mathbf{1 3}-\mathbf{1 5}$ quant \%; (b) 12 (0.8 equiv), basic $\mathrm{ZnCO}_{3}$, toluene, MS $4 \AA$, $60{ }^{\circ} \mathrm{C}$, yields of 16-18 in Table 1.

Table 1. Glycosylation of $\mathbf{1 2}$ by glycosyl donors 13-15 using basic zinc carbonate as a promoter in toluene.

\begin{tabular}{|c|c|c|c|c|c|c|}
\hline Entry & Donor & $\begin{array}{c}\text { Heating }{ }^{1} \\
\mathrm{ZnCO}_{3} \text { (equiv) }\end{array}$ & $\begin{array}{l}\text { Time } \\
(\mathrm{min})\end{array}$ & Product & $\begin{array}{c}\text { Yield }^{3} \\
(\%)\end{array}$ & $\alpha: \beta^{4}$ \\
\hline 1 & 13 & $\Delta, 0.44$ & 80 & 16 & 70 & $\alpha$ only \\
\hline 2 & 13 & MW, 0.35 & 6 & 16 & 30 & $75: 25$ \\
\hline 3 & 14 & $\Delta, 0.44$ & 50 & 17 & 67 & $\beta$ only \\
\hline 4 & 14 & MW, 0.44 & 6 & 17 & 61 & $21: 79$ \\
\hline 5 & 14 & $\mathrm{MW}^{2}, 0.44$ & 2.3 & 17 & 37 & $12: 88$ \\
\hline 6 & 15 & $\Delta, 0.44$ & 50 & 18 & 67 & $\beta$ only \\
\hline 7 & 15 & $\mathrm{MW}, 0.44$ & 6 & 18 & 48 & $20: 80$ \\
\hline
\end{tabular}

${ }^{1}$ Method $\Delta$ : The reaction was conducted at $60^{\circ} \mathrm{C}$ with 1.25 equiv of a glycosyl donor and 1 equiv of an acceptor with the addition of $4 \AA$ MS $(0.08 \mathrm{~g}$ per $0.1 \mathrm{mmol}$ of donor). Method MW: The same but the reaction was conducted at $60^{\circ} \mathrm{C}$ with 1.25 equiv of a glycosyl donor and 1 equiv of an acceptor.

${ }^{2}$ The reaction was conducted at $120{ }^{\circ} \mathrm{C} .{ }^{3}$ Isolated yields. ${ }^{4}$ Anomeric ratios were determined by the integration of appropriate peaks in the ${ }^{1} \mathrm{H}$ NMR spectra.

Furanosyl bromides 2,3,5-tri-O-acetyl-L-arabinofuranosyl bromide 13, 2,3,5-tri-Oacetyl-D-ribofuranosyl bromide 14, and 2,3-di-O-acetyl-5-O-benzoyl-D-apiofuranosyl bromide 15 as activated glycosyl donors were prepared in one step and in high yields starting from the corresponding peracylated furanoses 9-11. A solution of trimethylsilyl bromide in $\mathrm{CH}_{2} \mathrm{Cl}_{2}$ was used for quantitative bromination [70]. Due to the high instability of the bromides, the reaction mixtures were carefully concentrated, so that the temperature did not exceed $40^{\circ} \mathrm{C}$, and used directly for further glycosylations.

Basic $\mathrm{ZnCO}_{3}$ (0.35-0.44 equiv) was used as a promoter in toluene to optimize glycofuranosylation. The reaction of glycosyl donors 13-15 (1.25 equiv) with acceptor 12 (1 equiv) was conducted with addition of $4 \AA$ MS to prevent the formation of hydrolysis products. The reaction was carried out at $60{ }^{\circ} \mathrm{C}$ under conventional heating as well as under microwave irradiation (Table 1). Glycosylation of $\mathbf{1 2}$ by pentofuranosyl bromides 13-15 proceeded with higher stereoselectivity than the reaction with conformationally different pyranosyls studied in our previous work [33], giving only 1,2-trans-furanosides under conventional heating at $60^{\circ} \mathrm{C}$ (Table 1 , entries 1,3 , and 6). The reactivity under the studied conditions was comparable to the reactivity of reactive pentopyranosyls and higher than the reactivity of hexopyranosyls [33]. By using basic zinc carbonate as a promoter 
upon microwave irradiation, the reaction times were similarly significantly reduced from hours to minutes but the stereoselectivity of products had declined (Table 1, entries 2, 3, and 5) and some amount of 1,2-cis-furanosides was observed in ${ }^{1} \mathrm{H}$ NMR spectra. We applied the best glycosylation conditions (entries 1,3, and 6) to the reactions in preparative scale, and furanosides 16-18 were isolated in yields of about $70 \%$.

In the final synthetic step, the removal of the acetyl groups (benzoyl group for apiofuranozid 17) under Zemplén conditions proceeded smoothly (Scheme 2) but purification of the target glycosides 6-8 was laborious. The phenolic substances were absorbed and probably oxidized on silica gel, and the yields were, therefore, lower (30-40\%). Trouble-free purification of polyphenols by preparative chromatography still remains a challenge.

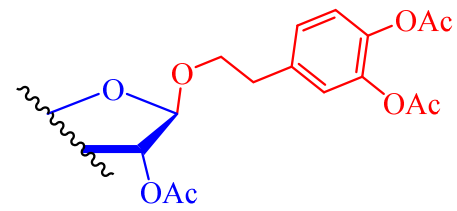

$16-18$

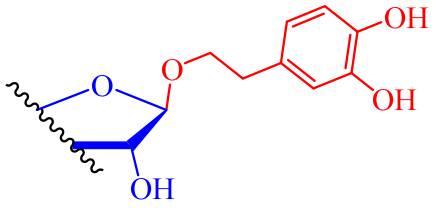

6 - 8

Scheme 2. Deprotection of furanosides. Reagents and conditions: (a) $0.5 \mathrm{M} \mathrm{MeONa} / \mathrm{MeOH}, 4{ }^{\circ} \mathrm{C}-\mathrm{rt}$, $644 \%, 736 \%$, and $831 \%$.

\subsection{Cell-Free Assays}

\subsubsection{Reducing Power Assay and DPPH Radical Scavenging Activity}

The electron-donating ability $\left(\mathrm{Fe}^{3+} / \mathrm{Fe}^{2+}\right.$ reduction) of the studied PEGFs $\mathbf{5} \mathbf{a}, \mathbf{5} \mathbf{b}$, and 6-8 was used to monitor their antioxidant properties. The reducing power of gallic acid (GA) was compared with all other tested compounds. Based on experimental results, we can conclude that HOT and hydroxytyrosol analogues (HOTFRU, HOTARA, HOTAPI, and HOTRIB) exhibited the most potent and concentration-dependent reduction capacity (Table 2). The reducing effect of $\mathrm{T}$ and TYBFRU in the concentration range tested was much lower than that of GA as well as the other hydroxytyrosol analogues $\mathbf{5 b}$ and $\mathbf{6 - 8}$ (Table 2).

The DPPH assay was used to compare the radical scavenging activity of the tested compounds. As shown in Table 2, the DPPH radical scavenging of HOT and HOT furanosides (HOTFRU, HOTARA, HOTAPI, and HOTRIB) was comparable with GA (known to be a strong antioxidant agent and used as a standard). T and TYBFRU exhibited the lowest DPPH-radical-scavenging activities (Table 2).

The highest reducing power and antioxidant activity demonstrated by HOT and HOT furanosides detected by us and as reviewed also by Karković et al. [3] could be attributed to the catechol moiety in their structures.

\subsubsection{Assessment of DNA-Damaging/-Protective Potential}

Electrophoretic monitoring of structural changes induced in plasmid DNA by treatment with the tested compounds is shown in Figure 3. Analogues were tested for their DNA-damaging effects (pBR322 plasmid DNA treated with different concentrations of tested compounds; wells 3-6) and their potential DNA-protective effects in the presence of $\mathrm{Fe}^{2+}$ ions (wells 7-10). $\mathrm{Fe}^{2+}$ treatment of pBR322 plasmid generated single-strand and double-strand breaks, resulting in plasmid relaxation into open circular (form II) or linear (form III) forms (Figure 3, well 2). Similarly to the negative standard represented by the supercoiled pDNA (form I) (Figure 3, well 1), none of the tested compounds changed the mobility of the supercoiled pDNA topoisomers in the given concentration ranges (0.01-10 mM). Moreover, DNA-protective effects of T, HOT, TYBFRU, HOTFRU, and HOTAPI were manifested in a dose-dependent manner (Figure $3 a-d, f)$. HOTARA and HOTRIB displayed only weak DNA-protective activities, as bands representing open relaxed circular and linear forms were present at all tested concentrations (Figure 3e,g). 
Table 2. Antioxidant activity of aglycones $\mathbf{1}$ and $\mathbf{2}$ and PEGFs $\mathbf{5 a}, \mathbf{5 b}$, and 6-8.

\begin{tabular}{|c|c|c|c|}
\hline Compound & $\begin{array}{c}\text { Concentrations } \\
(\mathrm{mM})\end{array}$ & $\begin{array}{l}\text { Reducing Power }{ }^{1} \\
\text { (Absorbance) }\end{array}$ & $\begin{array}{c}\text { DPPH Scavenging } \\
(\%)\end{array}$ \\
\hline \multirow{4}{*}{$\mathrm{T}(\mathbf{1})$} & 10 & $0.089 \pm 0.042$ & $6.710 \pm 2.907$ \\
\hline & 1 & $0.094 \pm 0.012$ & $2.120 \pm 1.310$ \\
\hline & 0.1 & $0.048 \pm 0.027$ & $0.955 \pm 0.090$ \\
\hline & 0.01 & $0.051 \pm 0.043$ & $0.000 \pm 0.000$ \\
\hline \multirow{4}{*}{ HOT (2) } & 10 & nd & $82.710 \pm 8.200$ \\
\hline & 1 & $1.891 \pm 0.702$ & $81.137 \pm 7.947$ \\
\hline & 0.1 & $0.259 \pm 0.054$ & $15.763 \pm 1.488$ \\
\hline & 0.01 & $0.046 \pm 0.040$ & $0.000 \pm 0.000$ \\
\hline \multirow{4}{*}{ TYBFRU (5a) } & 10 & $0.147 \pm 0.038$ & $3.920 \pm 1.240$ \\
\hline & 1 & $0.099 \pm 0.037$ & $1.410 \pm 0.040$ \\
\hline & 0.1 & $0.051 \pm 0.029$ & $0.000 \pm 0.000$ \\
\hline & 0.01 & $0.051 \pm 0.035$ & $0.000 \pm 0.000$ \\
\hline \multirow{4}{*}{ HOTFRU (5b) } & 10 & nd & $84.170 \pm 14.467$ \\
\hline & 1 & $1.788 \pm 0.227$ & $78.980 \pm 13.150$ \\
\hline & 0.1 & $0.285 \pm 0.001$ & $14.260 \pm 20.167$ \\
\hline & 0.01 & $0.116 \pm 0.051$ & $5.870 \pm 8.301$ \\
\hline \multirow{4}{*}{ HOTARA (6) } & 10 & nd & $81.788 \pm 2.861$ \\
\hline & 1 & $1.527 \pm 0.589$ & $73.895 \pm 7.768$ \\
\hline & 0.1 & $0.276 \pm 0.093$ & $5.600 \pm 3.652$ \\
\hline & 0.01 & $0.167 \pm 0.122$ & $2.143 \pm 3.439$ \\
\hline \multirow{4}{*}{ HOTAPI (7) } & 10 & nd & $82.513 \pm 3.338$ \\
\hline & 1 & $1.883 \pm 0.923$ & $74.678 \pm 11.425$ \\
\hline & 0.1 & $0.274 \pm 0.081$ & $5.230 \pm 3.775$ \\
\hline & 0.01 & $0.124 \pm 0.038$ & $1.265 \pm 1.189$ \\
\hline \multirow{4}{*}{ HOTRIB (8) } & 10 & nd & $83.210 \pm 9.270$ \\
\hline & 1 & $2.304 \pm 0.045$ & $75.440 \pm 19.640$ \\
\hline & 0.1 & $0.364 \pm 0.045$ & $16.950 \pm 10.530$ \\
\hline & 0.01 & $0.135 \pm 0.057$ & $9.615 \pm 13.600$ \\
\hline \multirow{4}{*}{ GA } & 10 & nd & $91.609 \pm 6.011$ \\
\hline & 1 & $2.151 \pm 0.652$ & $88.454 \pm 6.240$ \\
\hline & 0.1 & $0.309 \pm 0.010$ & $25.720 \pm 11.839$ \\
\hline & 0.01 & $0.108 \pm 0.064$ & $3.088 \pm 4.963$ \\
\hline
\end{tabular}

${ }^{1}$ Data represent the means \pm standard deviations (SD) of three independent experiments; GA (gallic acid) is shown as a standard in both assays; nd (undetectable): the absorbance value is above the detection limit of a spectrophotometer.

The phenylethanoids ( $\mathrm{T}$ and HOT) are assumed to be folded into the gauche conformation of the hydroxyethyl chain, in which its $\mathrm{OH}$ group is oriented toward the aromatic ring [32]. This gauche conformer is stabilized by the presence of the $\mathrm{OH} \cdots \pi$ intramolecular interaction. A similar geometry of phenylethanoid aglycone was also suggested for glycopyranosides. Five-membered rings of glycofuranoses may adopt the envelope or twist conformations. According to observed vicinal interaction constants $\left({ }^{3} J\right)$ from ${ }^{1} \mathrm{H}$ NMR spectra of studied HOT glycofuranosides, we can assume the conformations of their furanoside rings to be from ${ }^{3} \mathrm{~T}_{2}$ to ${ }^{1} \mathrm{E}$. Protons $\mathrm{H}-1$ and $\mathrm{H}-2$ of pentofuranosides 6-8 are pseudoequatorial and protons $\mathrm{H}-3$ and $\mathrm{H}-4$ of fructofuranoside $5 \mathbf{a}$ are pseudoaxial $\left(J_{1,2}(6)=1.7 \mathrm{~Hz} ; J_{1,2}(7)=2.4 \mathrm{~Hz} ; J_{1,2}(8)=3.7 \mathrm{~Hz} ; J_{2,3}(6)=3.7 \mathrm{~Hz} ; J_{2,3}(8)=4.7 \mathrm{H}\right.$; $\left.J_{3,4}(5 \mathbf{b})=8.1 \mathrm{~Hz}[39]\right)$. These considerations are also generally consistent with a review article published by Lowary et al. [47]. 

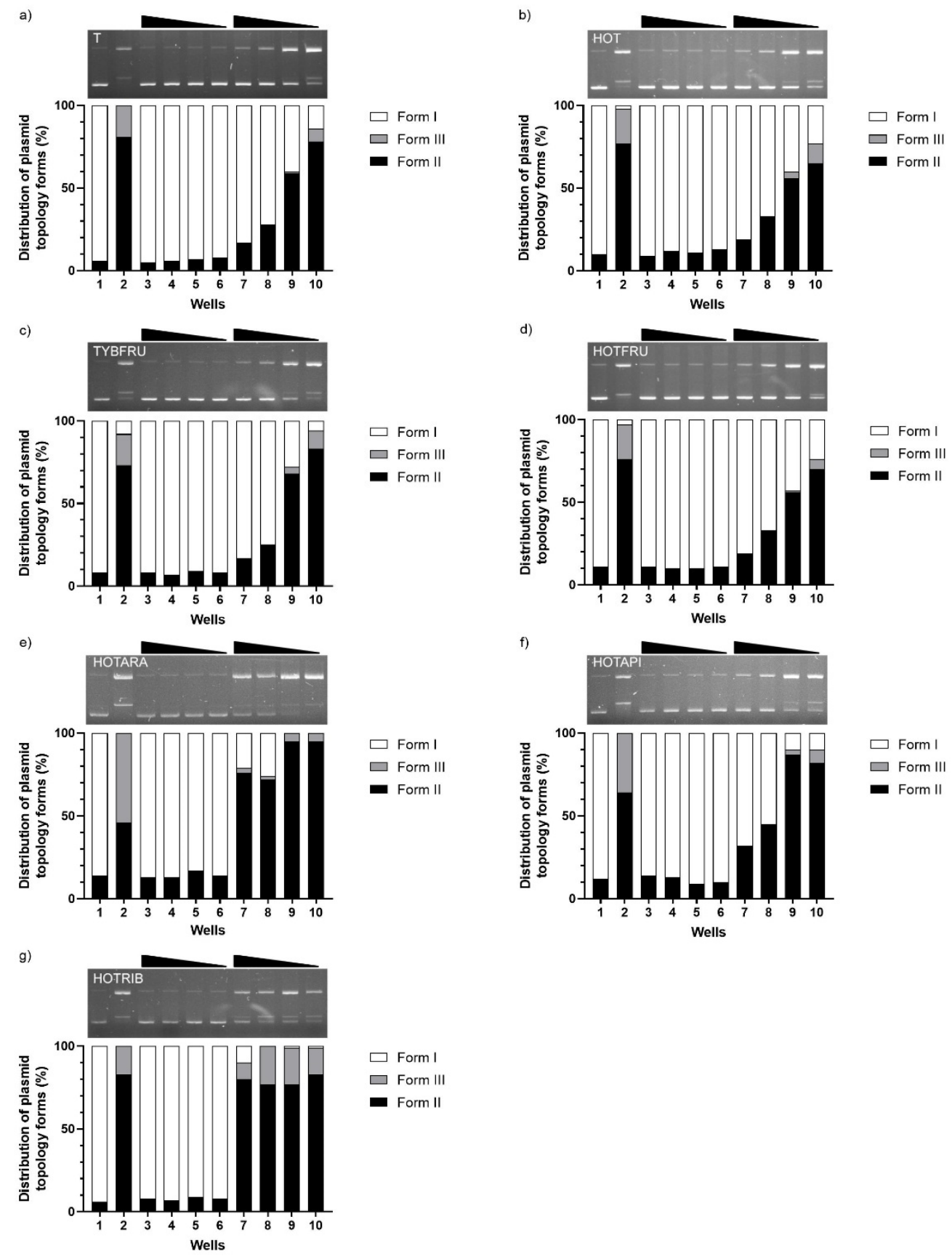

Figure 3. DNA-protective potential (DNA topology assay) of aglycones (a) T (1) and (b) HOT (2) and PEGFs (c) TYBFRU (5a), (d) HOTFRU (5b), (e) HOTARA (6), (f) HOTAPI (7), and (g) HOTRIB (8) against $\mathrm{Fe}^{2+}$-induced DNA damage in plasmid pBR322 presented as electrophoretograms as well as densitometric distribution of plasmid topology forms (\%). The order of wells in each gel: 1, NS or negative standard (intact pBR322); 2, PS or positive standard (pBR322 treated with $10 \mu \mathrm{M} \mathrm{Fe}{ }^{2+}$ ); 3-6, pBR322 treated with decreasing concentrations of T, HOT, and PEGFs (10-0.01 mM); 7-10, pBR322 treated with decreasing concentrations of T, HOT, and PEGFs $(10-0.01 \mathrm{mM})$ in the presence of $\mathrm{Fe}^{2+}$ ions. $\mathrm{Fe}^{2+}$ ions induce DNA breaks via a Fenton-like reaction, resulting in the conversion of plasmid topology from supercoiled (form I) to relaxed circular (form II) and/or linear (form III).

When comparing the results of the DNA topology assay for T and HOT or TYBFRU and HOTFRU, the compounds containing two ortho phenolic groups in their molecule were evidently more potent in the protective effect against DNA damage induced by $\mathrm{Fe}^{2+}$. Larger differences in the protective efficacy are perhaps visible between the individual HOT glycofuranosides HOTFRU and HOTAPI compared to HOTARA and HOTRIB (Figure 3). 
This supports our theory that if the HOT glycoside can acquire such a conformation that the free primary group of the $\mathrm{CH}_{2} \mathrm{OH}$ monosaccharide ring is close to the catechol moiety of the aglycone, it can help to stabilize the generated radical by forming a hydrogen bond [32]. Such a molecule geometry is excluded for HOTARA (6). The $\mathrm{CH}_{2} \mathrm{OH}$ group and aglycone are on the opposite sides of the plane of the furanoside ring. Ortho-diphenols of HOTFRU aglycone could interact in the oxidation state with $\mathrm{CH}_{2} \mathrm{OH}$ on the $\mathrm{C}-1$ furanoside ring. The primary $\mathrm{CH}_{2} \mathrm{OH}$ group on the $\mathrm{C}-3$ furanoside ring (HOTAPI, 7) is likely to be more favorable for interaction than the one on C-4 (HOTRIB, 8) (Scheme 3).

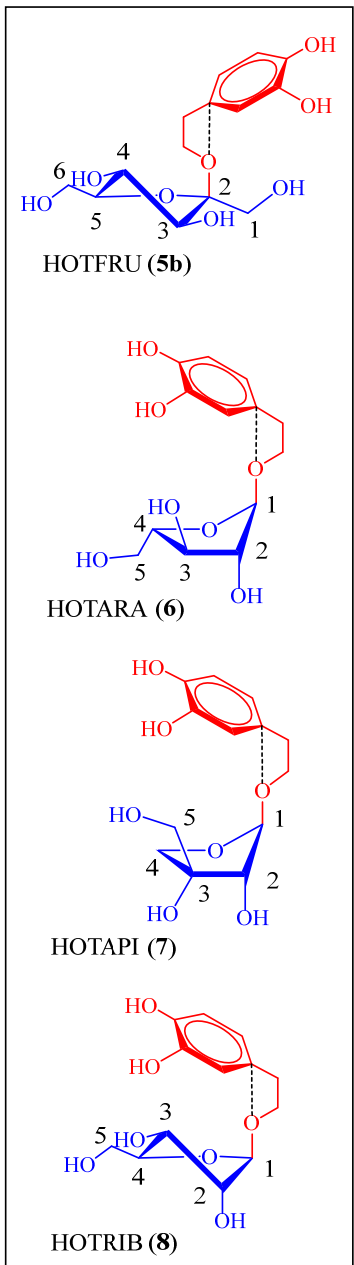

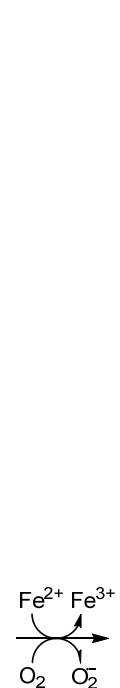

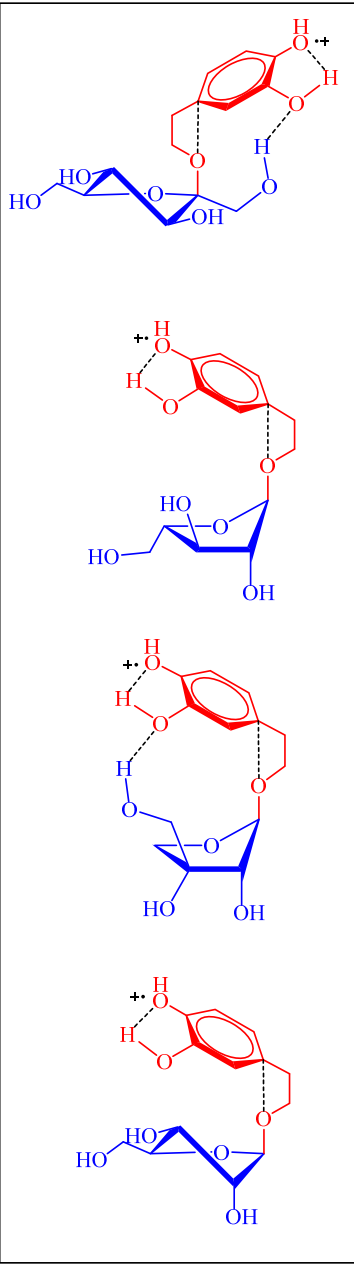

radical cations

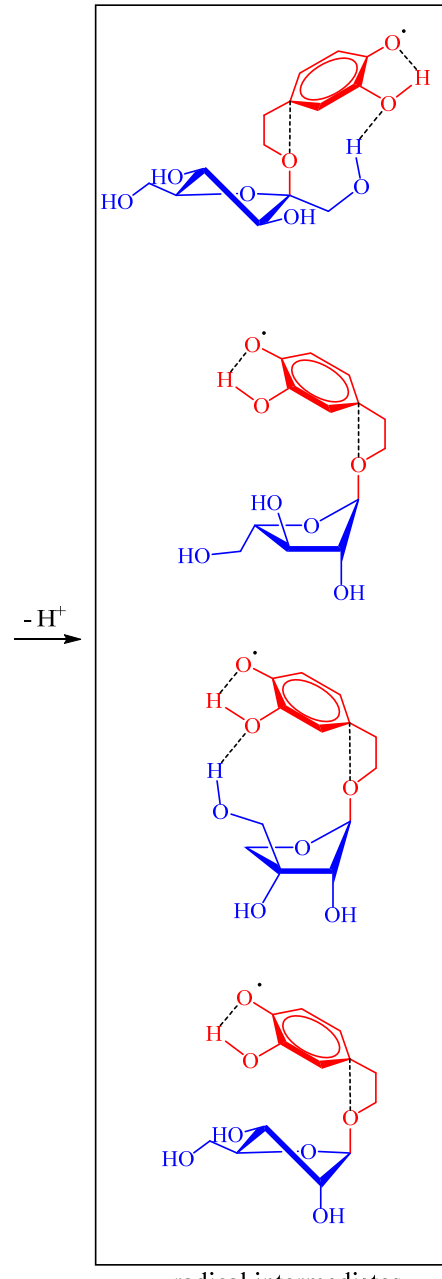

radical intermediates

Scheme 3. Probable conformers of $\mathbf{5 b}$ and $\mathbf{6}-\mathbf{8}$ and a plausible scavenging mechanism through a two-step sequential proton loss electron transfer reaction.

The potential interaction of the appropriate hydroxyl groups of glycofuranosides (such as primary 6-OH along with secondary 4-OH in HOTFRU) with the phosphate groups of plasmid DNA through the formation of a hydrogen bond could also affect the protective potential of a particular glycoside [32]. 


\subsection{Cellular Assays}

\subsubsection{Cell Viability}

The cytotoxicity of T, HOT, and synthesized PEGFs on HepG2 cells was evaluated by the MTT assay, a sensitive method for detecting the cellular toxicity via the measurement of enzymatic conversion of MTT in the mitochondria [71,72]. Loss of cell viability was significant after a $48 \mathrm{~h}$ exposure of HepG2 cells to T, HOT, TYBFRU, HOTARA, and HOTAPI at the three highest concentrations $(500-2000 \mu \mathrm{M})$, whereas for HOTFRU and HOTRIB, it was significant even at the two highest concentrations used for the treatment (1000 and $2000 \mu \mathrm{M})$, respectively. At 5-200 $\mu \mathrm{M}$ concentrations, T, HOT, and PEGFs did not reduce the viability of HepG2 cells (Figure 4).

\subsubsection{Evaluation of Potential Protective Effects on HepG2 Cells}

The potential DNA-damaging/-protective effects of T, HOT, and PEGFs at the concentrations ranging from 50 to $200 \mu \mathrm{M}$ were investigated using the comet assay on human hepatoma HepG2 cells. The conventional alkaline comet assay showed a slight increase in DNA damage after TYBFRU treatment at all concentrations tested, after $200 \mu \mathrm{M}$ HOT treatment, and after $100 \mu \mathrm{M}$ HOTAPI treatment (Figure 5).

The protective activity of T, HOT, and PEGFs was assessed from the decrease in DNA damage induced by $\mathrm{H}_{2} \mathrm{O}_{2}$ alone. Experimental results showed that $48 \mathrm{~h}$ pre-treatment of HepG2 cells with HOT, hydroxytyrosol PEGFs, and TYBFRU before exposure to $\mathrm{H}_{2} \mathrm{O}_{2}$ for 5 min caused a significant decrease in DNA migration in the comet tails in all tested concentrations compared to the positive standard (Figure 5). In comparison with $\mathrm{H}_{2} \mathrm{O}_{2}$ alone $(35.55 \%)$, which was used as a positive standard, it can be concluded that all the tested compounds except tyrosol (T) exert protective effects on human hepatoma HepG2 cells. Although TYBFRU exhibited a slight DNA-damaging effect in comparison with the negative standard, it manifested a significant DNA-protective effect when applied as a pre-treatment, unlike $\mathrm{T}$, which neither induced DNA damage alone nor protected HepG2 cells from $\mathrm{H}_{2} \mathrm{O}_{2}$ treatment. We could, therefore, suppose that fructosylation highlighted the protective potential of tyrosol.

Our results obtained with HOT are in agreement with Tutino et al. [73], who provided insights into the mechanisms of action of HOT in the context of inhibition of cell proliferation and prevention of oxidative stress in human hepatoma cells. The authors detected an increase in total cellular antioxidant activity after HOT treatment [73]. Our experiments supported this outcome in another manner, as a decreased level of DNA damage induced by $\mathrm{H}_{2} \mathrm{O}_{2}$. 

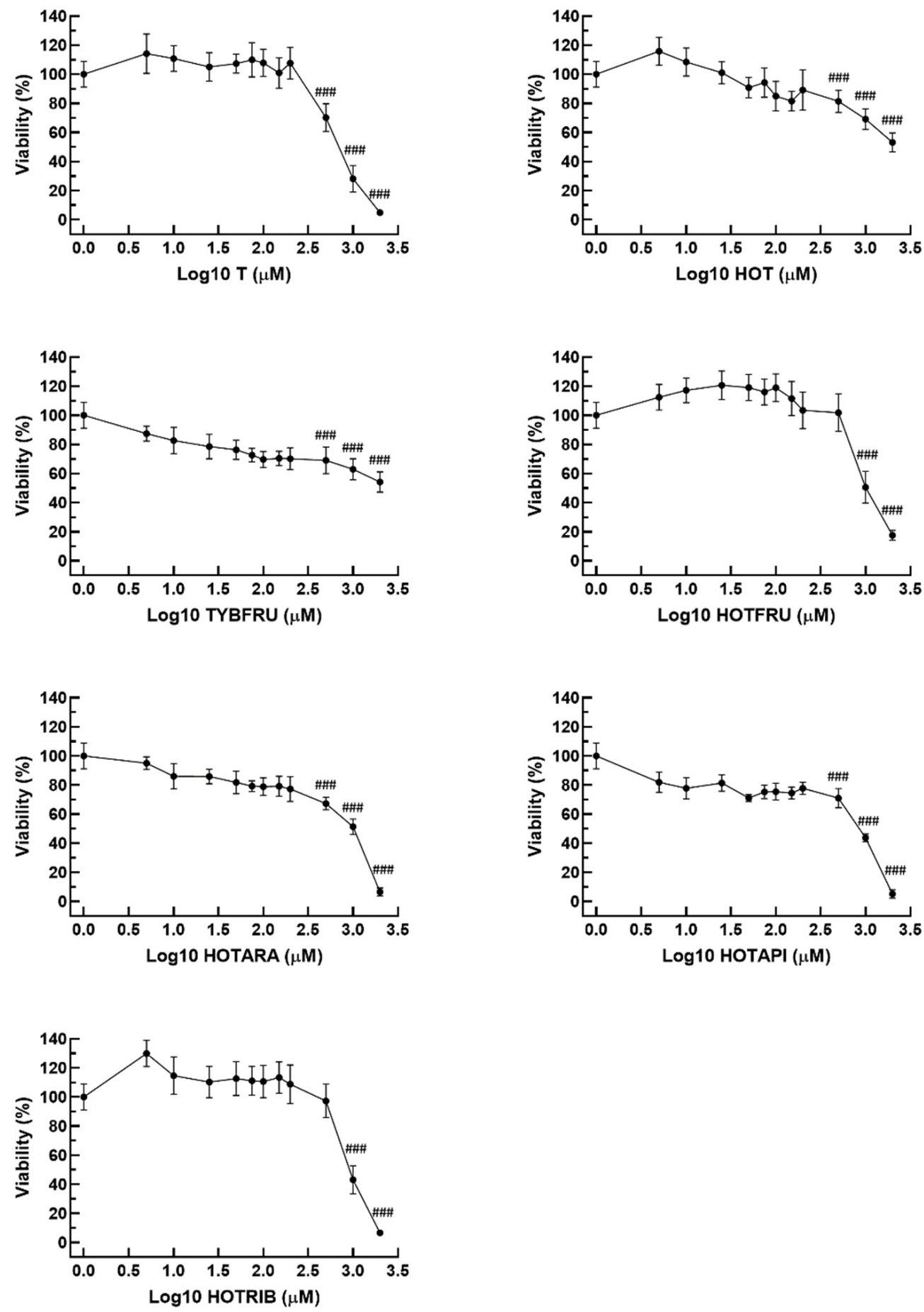

Figure 4. Viability of human hepatoma HepG2 cells (MTT test) after $48 \mathrm{~h}$ treatment with T, HOT, and PEGFs 5a, 5b, and 6-8; \#\#\# $p<0.001$ significant results in comparison to the negative standard (HepG2 cells treated with the solvent DMSO). 

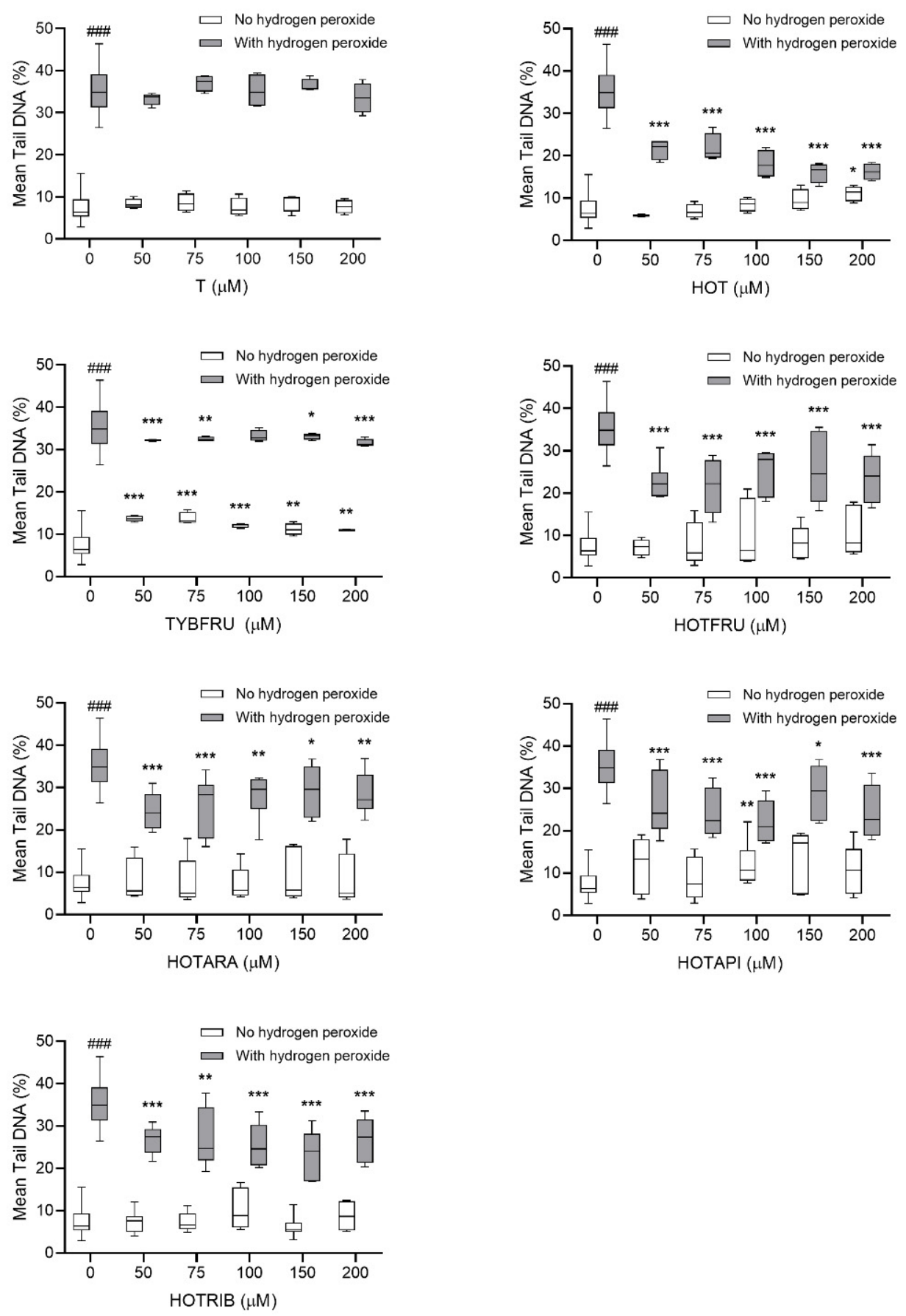

Figure 5. DNA damage (comet assay) caused by the combined treatment of T, HOT, and PEGFs 5a, 5b, and 6-8 (48 h) and $\mathrm{H}_{2} \mathrm{O}_{2}(300 \mu \mathrm{M}, 5$ min on ice) in human hepatoma HepG2 cells; \#\#\# $p<0.001$ significant results in comparison to the negative standard (HepG2 cells treated with the solvent DMSO); ${ }^{*} p<0.05,{ }^{* *} p<0.01$, and ${ }^{* *} p<0.001$ significant reduction in DNA damage in comparison to the positive standard (HepG2 cells treated with $\mathrm{H}_{2} \mathrm{O}_{2}$ ).

\section{Materials and Methods}

\subsection{General}

The reactions were performed with commercial reagents purchased from SigmaAldrich (St. Louis, MO, USA), Acrōs Organics (Geel, Belgium), Alfa Aesar (Karlsruhe, Germany), or Merck (Darmstadt, Germany). Toluene, dichloromethane, and methanol were dried $\left(\mathrm{Na}, \mathrm{P}_{2} \mathrm{O}_{5}\right)$ and distilled before use. Molecular sieves $(4 \AA)$ were microwave dried before use. Zinc carbonate basic, 97\%, Zn $>58.0 \%$ was purchased from Alfa Aesar 
(Karlsruhe, Germany). All reactions using sensitive reagents were carried out under an argon atmosphere.

Tyrosol (97\%) was purchased from Maybridge (Loughborough, Leicestershire, UK), and hydroxytyrosol was prepared according to [74]. Glycosylations under conventional heating were carried out in a preheated aluminum dry bath block in sealed vials. Microwave-assisted reactions were performed in a Discover CEM-SP microwave synthesizer ( $300 \mathrm{~W}$ maximum magnetron output power) using an external IR temperature measurement (CEM Corporation, Matthews, NC, USA). All microwave reactions were conducted in closed vessels under dynamic reaction conditions and cooled by simultaneous external flow of compressed air. The initial maximum power was set to $300 \mathrm{~W}$. When the reaction temperature was set to $120^{\circ} \mathrm{C}$ in the first set of screenings under mentioned conditions, the reaction temperature was reached in approximately $50 \mathrm{~s}$. TLC was performed on aluminum sheets precoated with silica gel $60 \mathrm{~F}_{254}$ (Merck, Darmstadt, Germany). Spots were visualized by UV light $\left(\lambda_{\max }=254 \mathrm{~nm}\right)$ and charred with $5 \%$ ethanolic sulfuric acid comprising $1 \%$ orcinol. Flash column chromatography was carried out on silica gel 60 (0.040-0.060 mm, Merck, Darmstadt, Germany or 0.035-0.075 mm, Acrōs Organics, Geel, Belgium) using distilled solvents (toluene (T), ethyl acetate (EA), and chloroform, methanol). ${ }^{1} \mathrm{H}$ NMR and ${ }^{13} \mathrm{C}$ NMR spectra were recorded at $25^{\circ} \mathrm{C}$ on $400 \mathrm{MHz}$ Bruker AVANCE III HD equipped with Prodigy CryoProbe (Bruker GmbH, Karlruhe, Germany). Chemical shifts were referenced to either TMS $\left(\delta 0.00, \mathrm{CDCl}_{3}\right.$ for $\left.{ }^{1} \mathrm{H}\right)$ or $\mathrm{HOD}(\delta 4.79$, $\mathrm{CD}_{3} \mathrm{OD}$ for $\left.{ }^{1} \mathrm{H}\right)$ and to internal $\mathrm{CDCl}_{3}\left(\delta 77.16,{ }^{13} \mathrm{C}\right)$ or $\mathrm{CD}_{3} \mathrm{OD}\left(\delta 49.00,{ }^{13} \mathrm{C}\right)$. Chemical shifts (in ppm) and coupling constants (in $\mathrm{Hz}$ ) were obtained by first-order analysis; assignments were derived from COSY and $\mathrm{H} / \mathrm{C}$ correlation spectra. The multiplicity of the ${ }^{13} \mathrm{C}$ NMR signals concerning the ${ }^{1} \mathrm{H}-{ }^{13} \mathrm{C}$ coupling was determined by the HSQC method. NMR spectra of new compounds are provided in the Supplementary Material. Optical rotations were measured on Perkin-Elmer 241 (PerkinElmer, Waltham, MA, USA) or Jasco P2000 (Jasco Products Company, Oklahoma City, OK, USA) polarimeters at $20^{\circ} \mathrm{C}$. High-resolution mass spectrometry was performed on a Premier Q-TOF mass spectrometer (Waters Corp, Milford, MA, USA) or an Orbitrap Velos PRO spectrometer (Thermo Fisher Scientific, Waltham, MA, USA).

Prepared PEGFs were kept at $4{ }^{\circ} \mathrm{C}, 0.1 \mathrm{M}$ stock solutions were kept in dimethyl sulfoxide (DMSO) at $-20^{\circ} \mathrm{C}$, and dilutions in appropriate reaction mixtures were done freshly just before the experiments. Hydrogen peroxide $\left(\mathrm{H}_{2} \mathrm{O}_{2}\right)$, ethidium bromide $(\mathrm{EtBr})$, and thiazolyl blue tetrazolium bromide (MTT) were purchased from Sigma-Aldrich Co., St. Louis, MO, USA. All other reagents and chemicals used were of analytical grade.

\subsection{Glycosylation Methods}

\subsubsection{Preparation of Glycofuranosyl Bromides 13-15}

To a solution of per-O-acylated furanose 9,10 , or $11(5 \mathrm{mmol})$ dissolved in dry $\mathrm{CH}_{2} \mathrm{Cl}_{2}$ $(9 \mathrm{~mL})$ and cooled to $0{ }^{\circ} \mathrm{C}$, trimethylsilyl bromide $(3.3 \mathrm{~mL}, 25 \mathrm{mmol})$ was added under argon and through the septum. The temperature of the reaction mixture was then allowed to rise to rt and stirred until the starting acetate has completely reacted according to TLC (4-15 h). The reaction mixture was concentrated at a temperature not exceeding $40^{\circ} \mathrm{C}$ and used immediately in the next reaction.

\subsubsection{General Procedure for 1,2-trans-Glycosylation under Conventional Heating Using Basic $\mathrm{ZnCO}_{3}$ as a Promoter. Method $\Delta$}

Acetylated HOT $12(57.1 \mathrm{mg}, 0.24 \mathrm{mmol})$ and glycofuranosyl bromide $(0.3 \mathrm{mmol}$, 1.25 equiv) were dissolved in dry toluene $(3 \mathrm{~mL})$ by short pre-stirring. After the dissolution of reactants, basic zinc carbonate $(57.7 \mathrm{mg}, 0.105 \mathrm{mmol}, 0.44$ equiv), together with powdered $4 \AA \mathrm{MS}(240 \mathrm{mg})$, was added to the mixture and the reaction was stirred at $60^{\circ} \mathrm{C}$. After completion of the reaction (monitored by TLC), the reaction mixture was diluted under vigorous stirring with ethyl acetate $(30 \mathrm{~mL})$. The heterogeneous mixture was then filtered through Celite 545, and the filter cake was washed with ethyl acetate. The collected 
filtrate was concentrated to dryness to give a crude product, which was purified by column chromatography on silica gel. The eluent toluene:ethyl acetate (4:1) were used to isolate per$\mathrm{O}$-acylated glycofuranosides 16-18. Yields and anomeric ratios of products are summarized in Table 1.

3.2.3. General Procedure for Microwave-Assisted Glycofuranosylation Using Basic $\mathrm{ZnCO}_{3}$ as a Promoter (Method MW)

Acetylated HOT 12 (57.1 mg, $0.24 \mathrm{mmol})$ and glycofuranosyl bromide (0.3 mmol, 1.25 equiv) were dissolved in dry toluene $(3 \mathrm{~mL})$ by short pre-stirring. After the dissolution of reactants, basic zinc carbonate ( 0.35 or 0.44 equiv), together with powdered $4 \AA$ MS (240 $\mathrm{mg})$, was added to the mixture. The cuvette containing the reaction mixture was placed into a microwave reactor, and the reaction was stirred using a dynamic method at a maximum power $300 \mathrm{~W}$, typically at 60 or $120^{\circ} \mathrm{C}$, for the time indicated in Table 1 . After the completion of the reaction (monitored by TLC), the compounds 16-18 were isolated from the reaction mixtures as described in the previous methods. Yields and anomeric ratios of the products are summarized in Table 1.

3.2.4. Typical Preparative Procedure for Glycofuranosylation under Conventional Heating Using Basic $\mathrm{ZnCO}_{3}$

Glycofuranosyl bromide (5.0 mmol, 1.25 equiv) and acetylated HOT $12(0.95 \mathrm{~g}, 4 \mathrm{mmol})$ were dissolved in dry toluene $(33 \mathrm{~mL})$ by short pre-stirring, followed by the addition of $4 \AA \mathrm{MS}$ (4 g). The reaction mixture was then heated to $60^{\circ} \mathrm{C}$, followed by the addition of basic zinc carbonate $(0.96 \mathrm{~g}, 1.87 \mathrm{mmol}, 0.46 \mathrm{equiv})$, and the mixture was stirred at $60{ }^{\circ} \mathrm{C}$ in an aluminum dry bath block for $50 \mathrm{~min}$. After the completion of the reaction, the mixture was diluted under vigorous stirring with ethyl acetate $(15 \mathrm{~mL})$. The suspension was then filtered through Celite 545, and the filter cake was washed with ethyl acetate. The supernatant and washings were combined and evaporated to dryness to give the crude product, which was further purified by chromatography on silica gel (toluene:ethyl acetate 10:1) to afford $16(1.370 \mathrm{~g}, 69 \%), 17(1.497 \mathrm{~g}, 67 \%)$, or $18(1.191 \mathrm{~g}, 60 \%)$.

\subsubsection{Characterization Data of Per-O-acylated Glycofuranosides 16-18}

2-[3,4-bis(acetoxy)phenyl]ethyl 2,3,5-tri-O-acetyl- $\alpha$-L-arabinofuranoside (16). Colorless syrup; $\mathrm{R}_{\mathrm{f}}=0.43(\mathrm{~T} / \mathrm{EA}, 1: 1, v / v) ;[\alpha]_{\mathrm{D}}{ }^{20}=-74.9^{\circ}\left(\mathrm{c}=1.0, \mathrm{CHCl}_{3}\right)$; $($ Table 1 , Entry 1); ${ }^{1} \mathrm{H}$ NMR (400 MHz, $\left.\mathrm{CDCl}_{3}\right), \delta 7.11$ (dd, $\left.J=8.3,1.8 \mathrm{~Hz}, 1 \mathrm{H}, \mathrm{CHPh}\right), 7.08$ (d, $J=8.2 \mathrm{~Hz}, 1 \mathrm{H}, \mathrm{CHPh}), 7.06(\mathrm{~d}, J=1.6 \mathrm{~Hz}, 1 \mathrm{H}, \mathrm{CHPh}), 5.05(\mathrm{~d}, J=1.6 \mathrm{~Hz}, 1 \mathrm{H}, \mathrm{H}-2)$, 5.01 (s, 1H, H-1), 4.95 (dd, $J=5.2,1.6 \mathrm{~Hz}, 1 \mathrm{H}, \mathrm{H}-3), 4.38$ (dd, $J=12.0,3.4 \mathrm{~Hz}, 1 \mathrm{H}, \mathrm{H}-$ $5 \mathrm{a}), 4.19(\mathrm{dd}, J=12.0,5.5 \mathrm{~Hz}, 1 \mathrm{H}, \mathrm{H}-5 \mathrm{~b}), 4.05(\mathrm{td}, J=5.3,3.5 \mathrm{~Hz}, 1 \mathrm{H}, \mathrm{H}-4), 3.93$ (dt, $\left.J=9.7,7.0 \mathrm{~Hz}, 1 \mathrm{H}, \mathrm{OCH}_{2} \mathrm{a}\right), 3.72\left(\mathrm{dt}, J=9.7,6.3 \mathrm{~Hz}, 1 \mathrm{H}, \mathrm{OCH}_{2} \mathrm{~b}\right), 2.89(\mathrm{t}, J=6.6 \mathrm{~Hz}, 2 \mathrm{H}$, $\left.\mathrm{OCH}_{2} \mathrm{CH}_{2}\right), 2.27\left(\mathrm{~s}, 3 \mathrm{H}, \mathrm{COCH}_{3}\right), 2.26\left(\mathrm{~s}, 3 \mathrm{H}, \mathrm{COCH}_{3}\right) 2.09\left(\mathrm{~s}, 6 \mathrm{H}, 2 \mathrm{COCH}_{3}\right), 2.07(\mathrm{~s}, 3 \mathrm{H}$, $\left.\mathrm{COCH}_{3}\right) ;{ }^{13} \mathrm{C} \mathrm{NMR}\left(101 \mathrm{MHz}, \mathrm{CDCl}_{3}\right), \delta 170.7\left(\mathrm{COCH}_{3}\right), 170.3\left(\mathrm{COCH}_{3}\right), 169.8\left(\mathrm{COCH}_{3}\right)$, $168.4\left(\mathrm{COCH}_{3}\right), 168.3\left(\mathrm{COCH}_{3}\right), 142.0(\mathrm{CPh}), 140.6(\mathrm{CPh}), 137.9(\mathrm{CPh}), 127.2(\mathrm{CHPh})$, $123.9(\mathrm{CHPh}), 123.2(\mathrm{CHPh}), 105.6$ (C-1), $81.4(\mathrm{C}-2), 80.4(\mathrm{C}-4), 77.1(\mathrm{C}-3), 67.8\left(\mathrm{OCH}_{2} \mathrm{CH}_{2}\right)$, $63.3(\mathrm{C}-5), 35.4\left(\mathrm{OCH}_{2} \mathrm{CH}_{2}\right), 20.9\left(\mathrm{COCH}_{3}\right), 20.9\left(\mathrm{COCH}_{3}\right), 20.8\left(\mathrm{COCH}_{3}\right), 20.8\left(\mathrm{COCH}_{3}\right)$, $20.7\left(\mathrm{COCH}_{3}\right)$; HRMS (APCI): calcd. for $\mathrm{C}_{23} \mathrm{H}_{28} \mathrm{O}_{12}[\mathrm{M}+\mathrm{H}]^{+}=497.16535$, found 497.16529.

2-[3,4-Bis(acetoxy)phenyl]ethyl 5-O-benzoyl-2,3-di-O-acetyl- $\beta$-D-apiofuranoside (17). Colorless syrup; $\mathrm{R}_{\mathrm{f}}=0.48(\mathrm{~T} / \mathrm{EA}, 1: 1, v / v) ;[\alpha]_{\mathrm{D}}{ }^{20}=-53.9^{\circ}\left(\mathrm{c}=1.0, \mathrm{CHCl}_{3}\right)$; $($ Table 1 , Entry 3); ${ }^{1} \mathrm{H}$ NMR (400 MHz, $\left.\mathrm{CDCl}_{3}\right), \delta 8.10-8.07(\mathrm{~m}, 2 \mathrm{H}, \mathrm{CHBz}), 7.58(\mathrm{t}, J=7.4 \mathrm{~Hz}, 1 \mathrm{H}$, CHBz), 7.46 (t, J = 7.6 Hz, 2H, CHBz), 7.05-7.02 (m, 3H, CHPh), 5.43 (s, 1H, H-2), 5.00 (s, $1 \mathrm{H}, \mathrm{H}-1), 4.83(\mathrm{~d}, J=12.2 \mathrm{~Hz}, 1 \mathrm{H}, \mathrm{H}-5 \mathrm{a}), 4.74(\mathrm{~d}, J=12.2 \mathrm{~Hz}, 1 \mathrm{H}, \mathrm{H}-5 \mathrm{~b}), 4.17$ (s, 2H, $\mathrm{H}-4), 3.91\left(\mathrm{dt}, J=9.5,7.1 \mathrm{~Hz}, 1 \mathrm{H}, \mathrm{OCH}_{2} \mathrm{a}\right), 3.67\left(\mathrm{dt}, J=9.5,6.4 \mathrm{~Hz}, 1 \mathrm{H}, \mathrm{OCH}_{2} \mathrm{~b}\right), 2.88(\mathrm{t}$, $\left.J=6.7 \mathrm{~Hz}, 2 \mathrm{H}, \mathrm{OCH}_{2} \mathrm{CH}_{2}\right), 2.22\left(\mathrm{~s}, 3 \mathrm{H}, \mathrm{COCH}_{3}\right), 2.21\left(\mathrm{~s}, 3 \mathrm{H}, \mathrm{COCH}_{3}\right), 2.09\left(\mathrm{~s}, 3 \mathrm{H}, \mathrm{COCH}_{3}\right)$, $2.01\left(\mathrm{~s}, 3 \mathrm{H}, \mathrm{COCH}_{3}\right) ;{ }^{13} \mathrm{C} \mathrm{NMR}\left(101 \mathrm{MHz}, \mathrm{CDCl}_{3}\right), \delta 169.8\left(\mathrm{COCH}_{3}\right), 169.3\left(\mathrm{COCH}_{3}\right)$, $168.4\left(\mathrm{COCH}_{3}\right), 168.3\left(\mathrm{COCH}_{3}\right), 166.0(\mathrm{COPh}), 142.0(\mathrm{CPh}), 140.7(\mathrm{CPh}), 133.3(\mathrm{CHBz})$, $131.6(\mathrm{CPh}), 130.0$ (2xCHBz), $129.8(\mathrm{CBz}), 128.5(2 \times \mathrm{CHBz}), 127.2(\mathrm{CHPh}), 123.9(\mathrm{CHPh})$, 123.3 (CHPh), 105.7 (C-1), 84.1 (C-3), 76.5 (C-2), 72.7 (C-4), $68.4\left(\mathrm{OCH}_{2} \mathrm{CH}_{2}\right), 63.9(\mathrm{C}-5)$, 
$35.5\left(\mathrm{OCH}_{2} \mathrm{CH}_{2}\right), 21.2\left(\mathrm{COCH}_{3}\right), 20.7\left(\mathrm{COCH}_{3}\right), 20.7\left(\mathrm{COCH}_{3}\right), 20.7\left(\mathrm{COCH}_{3}\right) ; \mathrm{HRMS}(\mathrm{ESI})$ : calcd. for $\mathrm{C}_{28} \mathrm{H}_{30} \mathrm{O}_{12}[\mathrm{M}+\mathrm{Na}]^{+}=581.16295$, found 581.16339 .

2-[3,4-Bis(acetoxy)phenyl]ethyl 2,3,5-tri-O-acetyl- $\beta$-D-ribofuranoside (18). Colorless syrup; $\mathrm{R}_{\mathrm{f}}=0.39(\mathrm{~T} / \mathrm{EA}, 1: 1, v / v) ;[\alpha]_{\mathrm{D}}{ }^{20}=-38.8^{\circ}\left(\mathrm{c}=1.0, \mathrm{CHCl}_{3}\right) ;($ Table 1 , Entry 6$) ;{ }^{1} \mathrm{H}$ NMR $\left(400 \mathrm{MHz}, \mathrm{CDCl}_{3}\right), \delta 7.09(\mathrm{~d}, J=8.3 \mathrm{~Hz}, 1 \mathrm{H}, \mathrm{CHPh}), 7.07(\mathrm{dd}, J=8.3,1.7 \mathrm{~Hz}, 1 \mathrm{H}$, CHPh), $7.03(\mathrm{~d}, J=1.7 \mathrm{~Hz}, 1 \mathrm{H}, \mathrm{CHPh}), 5.25(\mathrm{dd}, J=6.7,4.8 \mathrm{~Hz}, 1 \mathrm{H}, \mathrm{H}-3), 5.21$ (dd, $J=4.9$, $1.0 \mathrm{~Hz}, 1 \mathrm{H}, \mathrm{H}-2), 4.98$ (d, $J=1.0 \mathrm{~Hz}, 1 \mathrm{H}, \mathrm{H}-1), 4.28-4.23$ (m, 1H, H-4), 4.23 (dd, $J=11.8$, $3.7 \mathrm{~Hz}, 1 \mathrm{H}, \mathrm{H}-5 \mathrm{a}), 3.95(\mathrm{dd}, J=11.3,5.8 \mathrm{~Hz}, 1 \mathrm{H}), 3.92\left(\mathrm{dt}, J=9.5,7.0 \mathrm{~Hz}, 1 \mathrm{H}, \mathrm{OCH}_{2} \mathrm{a}\right)$, $3.60\left(\mathrm{dt}, J=9.5,6.8 \mathrm{~Hz}, 1 \mathrm{H}, \mathrm{OCH}_{2} \mathrm{~b}\right), 2.85\left(\mathrm{t}, J=6.9 \mathrm{~Hz}, 2 \mathrm{H}, \mathrm{OCH}_{2} \mathrm{CH}_{2}\right), 2.26\left(\mathrm{~s}, 1 \mathrm{H}, \mathrm{CH}_{3}\right)$, $2.26\left(\mathrm{~s}, 1 \mathrm{H}, \mathrm{CH}_{3}\right), 2.09\left(\mathrm{~s}, 1 \mathrm{H}, \mathrm{CH}_{3}\right), 2.05\left(\mathrm{~s}, 1 \mathrm{H}, \mathrm{CH}_{3}\right), 2.04\left(\mathrm{~s}, 1 \mathrm{H}, \mathrm{CH}_{3}\right) ;{ }^{13} \mathrm{C} \mathrm{NMR}(101 \mathrm{MHz}$, $\left.\mathrm{CDCl}_{3}\right), \delta 170.7\left(\mathrm{COCH}_{3}\right), 169.8\left(\mathrm{COCH}_{3}\right), 169.7\left(\mathrm{COCH}_{3}\right), 168.4\left(\mathrm{COCH}_{3}\right), 168.4\left(\mathrm{COCH}_{3}\right)$, $142.0(\mathrm{CPh}), 140.7(\mathrm{CPh}), 137.5(\mathrm{CPh}), 127.2(\mathrm{CHPh}), 124.0(\mathrm{CHPh}), 123.3(\mathrm{CHPh}), 105.2(\mathrm{C}-$ 1), $78.7(\mathrm{C}-4), 74.8(\mathrm{C}-2), 71.7(\mathrm{C}-3), 68.4\left(\mathrm{OCH}_{2}\right), 64.8(\mathrm{C}-5), 35.4\left(\mathrm{OCH}_{2} \mathrm{CH}_{2}\right), 20.9\left(\mathrm{COCH}_{3}\right)$, $20.7\left(\mathrm{COCH}_{3}\right), 20.7\left(\mathrm{COCH}_{3}\right), 20.7\left(\mathrm{COCH}_{3}\right), 20.6\left(\mathrm{COCH}_{3}\right)$; HRMS (ESI): calcd. for $\mathrm{C}_{23} \mathrm{H}_{28} \mathrm{O}_{12}[\mathrm{M}+\mathrm{Na}]^{+}=519.14730$, found 519.14694 .

\subsection{Deacylation of Per-O-Acylated Glycofuranosides 16-18}

Per-O-acetylated glycofuranoside $(2 \mathrm{mmol})$ was dissolved in dry $\mathrm{MeOH}(30 \mathrm{~mL})$ and cooled to $4{ }^{\circ} \mathrm{C}$, and $0.5 \mathrm{M} \mathrm{MeONa}(3.4 \mathrm{~mL})$ was added dropwise. The mixture was stirred at $4{ }^{\circ} \mathrm{C}$ until completion of the reaction was indicated by TLC (EtOAc:MeOH 6:1). The mixture was neutralized to $\mathrm{pH} 5$ with Dowex ${ }^{\circledR} 50 \mathrm{WX} 8$ (H+ form). The resin was then filtered off, and the filtrate was evaporated to dryness at temperature not higher than $40^{\circ} \mathrm{C}$. The residue was purified by column chromatography on silica gel (EtOAc:MeOH 6:1) and concentrated.

2-(3,4-Dihydroxyphenyl)ethyl $\alpha$-L-arabinofuranoside (6). Yield $44 \%$. Colorless syrup; $\mathrm{R}_{\mathrm{f}}=0.48(\mathrm{EA} / \mathrm{MeOH}, 9: 1, v / v) ;[\alpha]_{\mathrm{D}}{ }^{20}=-21.8^{\circ}\left(c\right.$ 1.0, $\left.\mathrm{CH}_{3} \mathrm{OH}\right) ;{ }^{1} \mathrm{H}$ NMR $(400 \mathrm{MHz}$, $\left.\mathrm{CD}_{3} \mathrm{OD}\right), \delta 6.72-6.69(\mathrm{~m}, 1 \mathrm{H}, \mathrm{CHPh}), 6.68(\mathrm{~d}, J=4.1 \mathrm{~Hz}, 1 \mathrm{H}, \mathrm{CHPh}), 6.57(\mathrm{dd}, J=8.1,2.1 \mathrm{~Hz}$, $1 \mathrm{H}, \mathrm{CHPh}), 4.90(\mathrm{~d}, J=1.7 \mathrm{~Hz}, 1 \mathrm{H}, \mathrm{H}-1), 3.98(\mathrm{dd}, J=3.7,1.7 \mathrm{~Hz}, 1 \mathrm{H}, \mathrm{H}-2), 3.92(\mathrm{~d}, J=3.2 \mathrm{~Hz}$, $1 \mathrm{H}, \mathrm{H}-4), 3.89\left(\mathrm{dt}, J=9.7,7.2 \mathrm{~Hz}, 1 \mathrm{H}, \mathrm{OCH}_{2} \mathrm{a}\right), 3.84(\mathrm{dd}, J=6.4,3.7 \mathrm{~Hz}, 1 \mathrm{H}, \mathrm{H}-3), 3.77(\mathrm{dd}$, $J=11.8,3.2 \mathrm{~Hz}, 1 \mathrm{H}, \mathrm{H}-5 \mathrm{a}), 3.67(\mathrm{dd}, J=12.1,5.3 \mathrm{~Hz}, 1 \mathrm{H}, \mathrm{H}-5 \mathrm{~b}), 3.61(\mathrm{dt}, J=9.7,7.2 \mathrm{~Hz}, 1 \mathrm{H}$, $\left.\mathrm{OCH}_{2} \mathrm{~b}\right), 2.77\left(\mathrm{t}, J=7.1 \mathrm{~Hz}, 2 \mathrm{H}, \mathrm{OCH}_{2} \mathrm{CH}_{2}\right) ;{ }^{13} \mathrm{C} \mathrm{NMR}\left(101 \mathrm{MHz}, \mathrm{CD}_{3} \mathrm{OD}\right), \delta 146.1(\mathrm{CPh})$, 144.6 (CPh), $131.8(\mathrm{CPh}), 121.2(\mathrm{CHPh}), 117.0$ (CHPh), 116.3 (CHPh), 109.4 (C-1), 85.3 (C-4), 83.5 (C-2), $78.7(\mathrm{C}-3), 70.0\left(\mathrm{OCH}_{2}\right), 63.0(\mathrm{C}-5), 36.5\left(\mathrm{OCH}_{2} \mathrm{CH}_{2}\right)$; HRMS (ESI): calcd. for $\mathrm{C}_{13} \mathrm{H}_{18} \mathrm{O}_{7}[\mathrm{M}+\mathrm{Na}]^{+}=309.09447$; found 309.09447.

2-(3,4-Dihydroxyphenyl)ethyl $\beta$-D-apiofuranoside (7). Yield 36\%. Colorless syrup; $\mathrm{R}_{\mathrm{f}}=0.51\left(\mathrm{CHCl}_{3} / \mathrm{MeOH}, 3: 1, v / v\right) ;[\alpha]_{\mathrm{D}}{ }^{20}=-12.9^{\circ}\left(c 1,0, \mathrm{CH}_{3} \mathrm{OH}\right) .{ }^{1} \mathrm{H} \mathrm{NMR}(400 \mathrm{MHz}$, $\left.\mathrm{CD}_{3} \mathrm{OD}\right), \delta 6.67(\mathrm{~d}, J=8.0 \mathrm{~Hz}, 2 \mathrm{H}, \mathrm{CHPh}), 6.66(\mathrm{~d}, J=2.0 \mathrm{~Hz}, 1 \mathrm{H}, \mathrm{CHPh}), 6.53(\mathrm{dd}$, $J=8.0,2.1 \mathrm{~Hz}, 1 \mathrm{H}, \mathrm{CHPh}), 4.92(\mathrm{~d}, J=2.5 \mathrm{~Hz}, 1 \mathrm{H}, \mathrm{H}-1), 3.87(\mathrm{~d}, J=9.6 \mathrm{~Hz}, 1 \mathrm{H}, \mathrm{H}-4 \mathrm{a})$, $3.84(\mathrm{~d}, J=2.4 \mathrm{~Hz}, 1 \mathrm{H}, \mathrm{H}-2), 3.80\left(\mathrm{dt}, J=9.5,7.2 \mathrm{~Hz}, 2 \mathrm{H}, \mathrm{OCH}_{2} \mathrm{a}\right), 3.73(\mathrm{~d}, J=9.7 \mathrm{~Hz}, 1 \mathrm{H}, \mathrm{H}-$ 4b), $3.57\left(\mathrm{dt}, J=9.6,7.0 \mathrm{~Hz}, 2 \mathrm{H}, \mathrm{OCH}_{2} \mathrm{~b}\right), 3.55(\mathrm{~d}, J=11.5 \mathrm{~Hz}, 1 \mathrm{H}, \mathrm{H}-5 \mathrm{a}), 3.51(\mathrm{~d}, J=11.5 \mathrm{~Hz}$, $1 \mathrm{H}, \mathrm{H}-5 \mathrm{~b}), 2.71\left(\mathrm{t}, J=7.1 \mathrm{~Hz}, 2 \mathrm{H}, \mathrm{OCH}_{2} \mathrm{CH}_{2}\right) ;{ }^{13} \mathrm{C} \mathrm{NMR}\left(101 \mathrm{MHz}, \mathrm{CD}_{3} \mathrm{OD}\right), \delta 146.1(\mathrm{CPh})$, 144.6 (CPh), 131.8 (CPh), 121.2 (CHPh), 117.0 (CHPh), 116.3 (CHPh), 110.4 (C-1), $80.4(\mathrm{C}-3)$, 78.0 (C-2), $74.9(\mathrm{C}-4), 70.5\left(\mathrm{OCH}_{2}\right), 65.5(\mathrm{C}-5), 36.6\left(\mathrm{OCH}_{2} \mathrm{CH}_{2}\right)$; HRMS (ESI): calcd. for $\mathrm{C}_{13} \mathrm{H}_{18} \mathrm{O}_{7}[\mathrm{M}+\mathrm{Na}]^{+}=309.09447$; found 309.09457 .

2-(3,4-Dihydroxyphenyl)ethyl $\beta$-D-ribofuranoside (8). Yield 31\%. Colorless syrup; $\mathrm{R}_{\mathrm{f}}=0.50\left(\mathrm{CHCl}_{3} / \mathrm{MeOH}, 3: 1, v / v\right) ;[\alpha]_{\mathrm{D}}{ }^{20}=-12.8^{\circ}\left(c 0.79, \mathrm{CH}_{3} \mathrm{OH}\right) .{ }^{1} \mathrm{H}$ NMR $(400 \mathrm{MHz}$, $\left.\mathrm{CD}_{3} \mathrm{OD}\right) \delta 6.67(\mathrm{~d}, J=8.5 \mathrm{~Hz}, 1 \mathrm{H}, \mathrm{CHPh}), 6.65(\mathrm{~d}, J=2.0 \mathrm{~Hz}, 1 \mathrm{H}, \mathrm{CHPh}), 6.53(\mathrm{dd}, J=8.0,2.1$ $\mathrm{Hz}, 1 \mathrm{H}, \mathrm{CHPh}), 4.85\left(1 \mathrm{H}, \mathrm{H}-1\right.$, overlapping with $\left.\mathrm{CD}_{3} \mathrm{OD}\right), 4.00(\mathrm{dd}, J=6.9,4.7 \mathrm{~Hz}, 1 \mathrm{H}, \mathrm{H}-3)$, $3.91(\mathrm{td}, J=6.8,3.4 \mathrm{~Hz}, 1 \mathrm{H}, \mathrm{H}-4), 3.90-3.83\left(\mathrm{~m}, 2 \mathrm{H}, \mathrm{H}-2\right.$ overlapping with $\left.\mathrm{OCH}_{2} \mathrm{a}\right), 3.65(\mathrm{dd}$, $J=11.7,3.5 \mathrm{~Hz}, 1 \mathrm{H}, \mathrm{H}-5 \mathrm{a}), 3.54\left(\mathrm{dt}, J=9.5,6.9 \mathrm{~Hz}, 1 \mathrm{H}, \mathrm{OCH}_{2} \mathrm{~b}\right), 3.43(\mathrm{dd}, J=11.7,6.7 \mathrm{~Hz}$, $1 \mathrm{H}, \mathrm{H}-5 \mathrm{~b}), 2.69\left(\mathrm{t}, J=7.0 \mathrm{~Hz}, 2 \mathrm{H}, \mathrm{OCH}_{2} \mathrm{CH}_{2}\right) ;{ }^{13} \mathrm{C} \mathrm{NMR}\left(101 \mathrm{MHz}, \mathrm{CD}_{3} \mathrm{OD}\right) \delta 146.1(\mathrm{CPh})$, 144.6 (CPh), 131.8 (CPh), 121.2 (CHPh), 117.1 (CHPh), 116.2 (CHPh), 108.6 (C-1), 84.8 (C-4), 76.3 (C-2), 72.9 (C-3), 70.0, $\left(\mathrm{OCH}_{2}\right), 65.2(\mathrm{C}-5), 36.5\left(\mathrm{OCH}_{2} \mathrm{CH}_{2}\right)$; HRMS (ESI): calcd. for $\mathrm{C}_{13} \mathrm{H}_{18} \mathrm{O}_{7}[\mathrm{M}+\mathrm{Na}]^{+}=309.09447$; found 309.09448 . 


\subsection{Biochemical Assays}

\subsubsection{Antioxidant Assays}

Free aglycones $\mathbf{1}$ and $\mathbf{2}$ and PEGFs $\mathbf{5 a}, \mathbf{5 b}$, and 6-8 were evaluated for their reducing power according to [75] and [76]. A series of T, HOT, PEGFs, and standard gallic acid (GA) at different concentrations $(10-0.01 \mathrm{mM})$ were prepared and mixed in $1 \mathrm{~mL}$ of methanol with $2.5 \mathrm{~mL}$ phosphate buffer $(0.2 \mathrm{M}, \mathrm{pH}=6.6)$ and $2.5 \mathrm{~mL}$ potassium ferricyanide $\left[\mathrm{K}_{3} \mathrm{Fe}(\mathrm{CN})_{6}\right](1 \%)$. The mixtures were incubated at $50{ }^{\circ} \mathrm{C}$ for $20 \mathrm{~min}$. Then, trichloroacetic acid $(2.5 \mathrm{~mL}, 10 \%)$ was added to each sample and the mixture centrifuged at $900 \times \mathrm{g}$ for $10 \mathrm{~min}$. Finally, $2.5 \mathrm{~mL}$ of the upper layer from supernatants was mixed with $2.5 \mathrm{~mL}$ of distilled water and $0.5 \mathrm{~mL}$ of $0.1 \% \mathrm{FeCl}_{3}$ and the spectrophotometer GENESYS ${ }^{\mathrm{TM}}$ $10 \mathrm{Bio}$, Spectronic, was used to measure the absorbance at the wavelength of $700 \mathrm{~nm}$ for the samples and the standard solutions.

Aglycones and PEGFs were evaluated for their ability to scavenge DPPH (1,1-diphenyl2-picrylhydrazyl) radicals by the assay modified by [77] and by us [32], as well. In brief, $1 \mathrm{~mL}$ of methanolic DPPH solution at the concentration of $0.05 \mathrm{mg} / \mathrm{mL}$ was mixed with a series of $50 \mu \mathrm{L}$ aliquots of various concentrations of T, HOT, and PEGFs (10-0.01 mM). GA was used as a standard in the same concentration range. The test tubes were vigorously shaken and left to incubate in dark at room temperature for $20 \mathrm{~min}$. The absorbance of samples, standard, and control (pure methanol) was measured using a GENESYS ${ }^{\mathrm{TM}} 10$ Bio, Spectronic, spectrophotometer at the wavelength of $517 \mathrm{~nm}$. The percentage of scavenging capacity of T, HOT, and PEGFs was calculated by the formula

$$
\text { Scavenging capacity }(\%)=100 \times\left(\mathrm{A}_{\text {control }}-\mathrm{A}_{\text {sample }}\right) / \mathrm{A}_{\text {control }}
$$

where $\mathrm{A}_{\text {sample }}$ is the sample's absorbance or the absorbance of the standard and $\mathrm{A}_{\text {control }}$ is the absorbance of the control's reaction (all reagents except the tested compounds).

\subsubsection{DNA Topology Assay}

The electrophoretic monitoring of topological changes in the plasmid DNA (pBR322) induced by $\mathrm{Fe}^{2+}$ ions was used to detect the DNA-protective/DNA-damaging potential of aglycones and PEGFs as described [78] and [32] in detail. In brief, the reaction mixture (final volume of $10 \mu \mathrm{L}$ ) consisted of plasmid DNA (200 $\mathrm{ng}$ in buffer) and either $\mathrm{Fe}^{2+}$ alone, or tested aglycones and PEGFs alone, or combinations of tested aglycones and PEGFs with $\mathrm{Fe}^{2+} . \mathrm{Fe}^{2+}$ ions induce in plasmid DNA breaks via free radical formation in a Fenton-like reaction. Analysis of DNA topology was carried out by gel electrophoresis (in 1.5\% agarose for $60 \mathrm{~min} / 60 \mathrm{~V})$. The DNA was stained with $\operatorname{EtBr}(1 \mathrm{mg} / \mathrm{mL})$ and visualized by UV illumination (UV Transilluminator MiniBISPro, DNR Bio Imaging Systems Ltd.). Increase in DNA strand breakage was assayed by measuring the conversion of supercoiled DNA, form I, to relaxed forms II and III. Densitometric quantification of plasmid topology forms $(\%)$ was carried out in the program ImageJ 1.53c (Wayne Rasband, National Institutes of Health, Kensington, MD, USA).

\subsection{Biological Assays In Vitro \\ 3.5.1. HepG2 Cell Line}

Human hepatoma HepG2 cells were used for cytotoxicity assessment and the investigation of potential genotoxic/protective action of aglycones and PEGFs. This cell line represents a useful and suitable tool for the detection of dietary genotoxic mutagens/carcinogens and various xenobiotics that could pose health risks to humans because of its functional drug-metabolizing abilities [79]. HepG2 cells were grown as an adherent culture in Dulbecco's Modified Eagle's Medium supplemented with 10\% heat-inactivated fetal bovine serum and antibiotics (penicillin $200 \mathrm{U} / \mathrm{mL} /$ streptomycin $100 \mu \mathrm{g} / \mathrm{mL}$ ) on plastic surfaces at $37{ }^{\circ} \mathrm{C}$ in a humidified atmosphere of $5 \% \mathrm{CO}_{2}: 95 \%$ air. All media and supplements used for the maintenance of cells in culture were purchased from Gibco Life Technologies BRL (Paisley, UK). 


\subsubsection{Cell Viability Assessment}

For determination of cytotoxicity by MTT assay [71,72], HepG2 cells were seeded into 96-well plates in a density of $2.5 \times 10^{6} /$ plate, cultivated for $24 \mathrm{~h}$ and treated with $\mathrm{T}, \mathrm{HOT}$, and PEGFs $(0-2000 \mu \mathrm{M})$. After the $48 \mathrm{~h}$ treatment, the cells were washed with phosphate buffered saline (PBS; Oxoid Limited, Hampshire, UK) and incubated with a medium containing MTT $(1 \mathrm{mg} / \mathrm{mL})$ for further $4 \mathrm{~h}$. Then, the medium was removed and replaced by $200 \mu \mathrm{L}$ of dimethyl sulfoxide (DMSO; SERVA Electrophoresis $\mathrm{GmbH}$, Heidelberg, Germany). The absorbance was measured at 540 and $690 \mathrm{~nm}$ using an Mark $^{\mathrm{TM}}$ microplate spectrophotometer (Bio-Rad Laboratories Inc., Berkeley, CA, USA). The viability of HepG2 cells was calculated by the formula

$$
\text { Viability }(\%)=100 \times \mathrm{A}_{\text {treated cells }} / \mathrm{A}_{\text {control cells }}
$$

\subsubsection{Alkaline Comet Assay (Single-Cell Gel Electrophoresis; SCGE)}

For the assessment of DNA-damaging/-protective effects of T, HOT, and PEGFs, the concentration range of 50-200 $\mu \mathrm{M}$ was selected for the $48 \mathrm{~h}$ treatment of HepG2 cells (their viability was above $70 \%$ ), followed by 5 min of incubation with $\mathrm{H}_{2} \mathrm{O}_{2}$. The conventional comet assay procedure was performed in alkaline conditions, as suggested in [80], and modified [32]. In brief, control, aglycones-, and PEGFs-treated HepG2 cells were trypsinized; centrifuged (1200 rpm, $5 \mathrm{~min}$ ); embedded in $0.75 \%$ low-melting-point agarose; and placed onto microscopic slides coated with $1 \%$ normal-melting-point agarose. After the solidification of the agarose, the respective part of the slides was treated with $\mathrm{H}_{2} \mathrm{O}_{2}$ (300 $\mu \mathrm{M}$ in PBS on ice in the dark), while the slides not treated with $\mathrm{H}_{2} \mathrm{O}_{2}$ were kept for $5 \mathrm{~min}$ in cold PBS. All slides were washed in PBS and placed in a lysis solution consisting of $2.5 \mathrm{M} \mathrm{NaCl}, 100 \mathrm{mM} \mathrm{Na}{ }_{2}$ EDTA, $10 \mathrm{mM}$ Tris- $\mathrm{HCl}(\mathrm{pH}=10.0)$, and $1 \%$ Triton $\mathrm{X}-100$ for $1 \mathrm{~h}$ at $4{ }^{\circ} \mathrm{C}$. After lysis, the slides were transferred into an electrophoresis buffer (300 $\mathrm{mM} \mathrm{NaOH}, 1 \mathrm{mM} \mathrm{Na} 2 \mathrm{EDTA}, \mathrm{pH}>13.0)$ for unwinding $\left(40 \mathrm{~min}\right.$ at $4{ }^{\circ} \mathrm{C}$ ) and subjected to electrophoresis (voltage $75 \mathrm{~V} / \mathrm{cm}$, amperage $\sim 300 \mathrm{~mA}$ ) for $30 \mathrm{~min}$ at $4{ }^{\circ} \mathrm{C}$. The slides were then neutralized in $0.4 \mathrm{M}$ Tris- $\mathrm{HCl}(\mathrm{pH}=7.5)$, drained, and stained with $\mathrm{EtBr}(5 \mu \mathrm{g} / \mathrm{mL})$.

At least $100 \mathrm{EtBr}$-stained nucleoids/sample/three slides in one electrophoresis run were scored with a Carl Zeiss AxioImager.Z2 fluorescence microscope using a computerized image analysis Metafer 5 (MetaSystems GmbH, Altlußheim, Germany). As a parameter for the expression of DNA damage, the percentage of DNA in the tail was chosen.

For statistical analysis of the cell viability results (\%) and the mean tail DNA (\%), SigmaPlot 12.5 and Prism GraphPad 8.4.3 were used. The normality of the distribution was tested by the Shapiro-Wilk test, and the equality of the data variance was tested by Levene's test. If normally distributed, differences were tested by unpaired $t$-test. If data were normally distributed but did not pass the equality-of-variance test, differences were tested using unpaired $t$-test with Welch's correction. If the data were non-normally distributed, a Mann-Whitney $U$ test was used. All tests were two-tailed and performed at the significance level $\alpha=0.05$. The $p<0.05$ was considered statistically significant for all analyses $\left({ }^{*} p<0.05 ;{ }^{* *} p<0.01 ;{ }^{* * *} p<0.001\right.$; \#\# $p<0.001$ for control comparison).

\section{Conclusions}

A series of new hydroxytyrosol 1,2-trans-glycofuranosides were prepared by modifying the Koenigs-Knorr conditions, using the environmentally friendly basic zinc carbonate as a promoter. The new glycofuranosides, as well as previously enzymatically prepared $\mathrm{T}$ and HOT fructofuranosides, were compared with their aglycones ( $\mathrm{T}$ and HOT) to determine a possible relationship between their structure, their antioxidant capacity, and their DNA-damaging and DNA-protective potential. The results showed that HOT glycofuranosides and HOT possess significant radical scavenging/antioxidant activities comparable to those of GA. The compounds protected plasmid DNA in a dose-dependent manner in the order HOT $=$ HOTFRU $>$ T $>$ HOTAPI $>$ TYBFRU. For glycofuranosides, the effectiveness of this protection can be explained by the different abilities of their primary hydroxyls 
to participate in radical stabilization together with ortho-diphenols of HOT aglycon. The compounds have no genotoxic effect on human HepG2 cells at the concentrations studied. HOT, HOTFRU, and HOTAPI were the best candidates for protection at the cellular level. However, it should be noted that in the concentration range of 5-500 $\mu \mathrm{M}$, HOTFRU and HOTRIB were less toxic to cells than HOT, T, and other PEGFs. HOTFRU has been shown to have antioxidant potential comparable to that of HOT at lower toxicity.

Supplementary Materials: The following are available online, Figures S1-S12: Copies of ${ }^{1} \mathrm{H}$ and ${ }^{13} \mathrm{C}$ NMR, spectra for new compounds: 16-18, 6-8.

Author Contributions: Conceptualization, M.M. and E.H.; methodology, P.K., E.H, E.G., A.Š., V.A., E.K.P., and M.M.; formal analysis, P.K., E.H., and M.M.; investigation, P.K., E.H., V.A., and E.K.P.; writing—original draft preparation, M.M.; writing—review and editing, E.H., V.M., and A.Š.; visualization, M.M. and E.H.; supervision, V.M.; project administration, V.M. and M.M.; funding acquisition, V.M. All authors have read and agreed to the published version of the manuscript.

Funding: This research was funded by the Slovak Research and Development Agency (grant no. APVV-18-0188) and by the Slovak Grant Agency for Science VEGA (grant no. 2/0126/19).

Institutional Review Board Statement: Not applicable.

Informed Consent Statement: Not applicable.

Data Availability Statement: Not applicable.

Acknowledgments: The authors wish to thank Jan Roška, (Cancer Research Institute, Biomedical Research Center, Slovak Academy of Sciences, Bratislava, Slovakia), for his assistance with the statistical analysis and the graphical design of the cellular assays results. The contribution of COST Action CA17128 "LIGNOCOST-Establishment of a Pan-European Network on the Sustainable Valorisation of Lignin," supported by European Cooperation in Science and Technology (COST), in promoting interaction, exchange of knowledge, and collaboration in the field of chemistry and transformation of natural phenolic substances, as well as support from the Research \& Development Operational Programme funded by the ERDF TRANSMED, ITMS 26240120008, and ITMS 26240220071 are also gratefully acknowledged.

Conflicts of Interest: The authors declare no conflict of interest.

Sample Availability: Samples of the compounds are not available from the authors.

\section{References}

1. Medawar, E.; Huhn, S.; Villringer, A.; Witte, V.A. The effects of plant-based diets on the body and the brain: A systematic review. Transl. Psychiatry 2019, 9, 226. [CrossRef]

2. Proshkina, E.; Shaposhnikov, M.; Moskalev, A. Genome-Protecting Compounds as Potential Geroprotectors. Int. J. Mol. Sci. 2020, 21, 4484. [CrossRef] [PubMed]

3. Marković Karković, A.; Torić, J.; Barbarić, M.; Jakobušić Brala, C. Hydroxytyrosol, tyrosol and derivatives and their potential effects on human health. Molecules 2019, 24, 2001. [CrossRef]

4. Tripoli, E.; Giammanco, M.; Tabacchi, G.; Di Majo, D.; Giammanco, S.; La Guardia, M. The phenolic compounds of olive oil: Structure, biological activity and beneficial effects on human health. Nutr. Res. Rev. 2005, 18, 98-112. [CrossRef] [PubMed]

5. Jiménez, C.; Riguera, R. Phenylethanoid glycosides in plants: Structure and biological activity. Nat. Prod. Rep. 1994, 11, 591-606. [CrossRef]

6. Fu, G.; Pang, H.; Wong, Y. Naturally Occurring Phenylethanoid Glycosides: Potential Leads for New Therapeutics. Curr. Med. Chem. 2008, 15, 2592-2613. [CrossRef]

7. Xue, Z.; Yang, B. Phenylethanoid glycosides: Research advances in their phytochemistry, pharmacological activity and pharmacokinetics. Molecules 2016, 21, 991. [CrossRef]

8. Wu, L.; Georgiev, M.I.; Cao, H.; Nahar, L.; El-Seedi, H.R.; Sarker, S.D.; Xiao, J.; Lu, B. Therapeutic potential of phenylethanoid glycosides: A systematic review. Med. Res. Rev. 2020, 40, 2605-2649. [CrossRef] [PubMed]

9. Tian, X.Y.; Li, M.X.; Lin, T.; Qiu, Y.; Zhu, Y.T.; Li, X.L.; Tao, W.D.; Wang, P.; Ren, X.X.; Chen, L.P. A review on the structure and pharmacological activity of phenylethanoid glycosides. Eur. J. Med. Chem. 2021, 209, 112563. [CrossRef]

10. Lo Giudice, V.; Faraone, I.; Bruno, M.R.; Ponticelli, M.; Labanca, F.; Bisaccia, D.; Massarelli, C.; Milella, L.; Todaro, L. Olive trees by-products as sources of bioactive and other industrially useful compounds: A systematic review. Molecules 2021, $26,5081$. [CrossRef] [PubMed] 
11. Carrara, M.; Kelly, M.T.; Roso, F.; Larroque, M.; Margout, D. Potential of Olive Oil Mill Wastewater as a Source of Polyphenols for the Treatment of Skin Disorders: A Review. J. Agric. Food Chem. 2021, 69, 7268-7284. [CrossRef]

12. Vann, K.R.; Sedgeman, C.A.; Gopas, J.; Golan-Goldhirsh, A.; Osheroff, N. Effects of Olive Metabolites on DNA Cleavage Mediated by Human Type II Topoisomerases. Biochemistry 2015, 54, 4531-4541. [CrossRef] [PubMed]

13. Rietjens, S.J.; Bast, A.; Haenen, G.R.M.M. New insights into controversies on the antioxidant potential of the olive oil antioxidant hydroxytyrosol. J. Agric. Food Chem. 2007, 55, 7609-7614. [CrossRef]

14. Ciriminna, R.; Meneguzzo, F.; Fidalgo, A.; Ilharco, L.M.; Pagliaro, M. Extraction, benefits and valorization of olive polyphenols. Eur. J. Lipid Sci. Technol. 2016, 118, 503-511. [CrossRef]

15. Robles-Almazan, M.; Pulido-Moran, M.; Moreno-Fernandez, J.; Ramirez-Tortosa, C.; Rodriguez-Garcia, C.; Quiles, J.L.; RamirezTortosa, M. Hydroxytyrosol: Bioavailability, toxicity, and clinical applications. Food Res. Int. 2018, 105, 654-667. [CrossRef]

16. De las Hazas, M.C.L.; Rubio, L.; Macia, A.; Motilva, M.J. Hydroxytyrosol: Emerging Trends in Potential Therapeutic Applications. Curr. Pharm. Des. 2018, 24, 2157-2179. [CrossRef]

17. Bertelli, M.; Kiani, A.K.; Paolacci, S.; Manara, E.; Kurti, D.; Dhuli, K.; Bushati, V.; Miertus, J.; Pangallo, D.; Baglivo, M.; et al Hydroxytyrosol: A natural compound with promising pharmacological activities. J. Biotechnol. 2020, 309, 29-33. [CrossRef] [PubMed]

18. Bernini, R.; Merendino, N.; Romani, A.; Velotti, F. Naturally Occurring Hydroxytyrosol: Synthesis and Anticancer Potential. Curr. Med. Chem. 2013, 20, 655-670. [CrossRef]

19. Vilaplana-Pérez, C.; Auñón, D.; García-Flores, L.A.; Gil-Izquierdo, A. Hydroxytyrosol and Potential Uses in Cardiovascular Diseases, Cancer, and AIDS. Front. Nutr. 2014, 1, 1-11. [CrossRef]

20. De Pablos, R.M.; Espinosa-Oliva, A.M.; Hornedo-Ortega, R.; Cano, M.; Arguelles, S. Hydroxytyrosol protects from aging process via AMPK and autophagy; a review of its effects on cancer, metabolic syndrome, osteoporosis, immune-mediated and neurodegenerative diseases. Pharmacol. Res. 2019, 143, 58-72. [CrossRef]

21. Turck, D.; Bresson, J.; Burlingame, B.; Dean, T.; Fairweather-Tait, S.; Heinonen, M.; Hirsch-Ernst, K.I.; Mangelsdorf, I.; McArdle, H.J.; Naska, A.; et al. Safety of hydroxytyrosol as a novel food pursuant to Regulation (EC) No 258/97. EFSA J. 2017, 15, 4728. [CrossRef]

22. Annunziata, F.; Contente, M.L.; Pinna, C.; Tamborini, L.; Pinto, A. Biocatalyzed flow oxidation of tyrosol to hydroxytyrosol and efficient production of their acetate esters. Antioxidants 2021, 10, 1142. [CrossRef]

23. Kalampaliki, A.D.; Giannouli, V.; Skaltsounis, A.L.; Kostakis, I.K. A three-step, gram-scale synthesis of hydroxytyrosol, hydroxytyrosol acetate, and 3,4-dihydroxyphenylglycol. Molecules 2019, 24, 3239. [CrossRef]

24. Bender, C.; Straßmann, S.; Heidrich, P. Cellular antioxidant effects and bioavailability of food supplements rich in hydroxytyrosol. Appl. Sci. 2021, 11, 4763. [CrossRef]

25. Visioli, F.; Galli, C.; Grande, S.; Colonnelli, K.; Patelli, C.; Galli, G. Nutrient metabolism—Research communication hydroxytyrosol excretion differs between rats and humans and depends on the vehicle of administration. J. Nutr. 2003, 133, 2612-2615. [CrossRef]

26. Granados-Principal, S.; Quiles, J.L.; Ramirez-Tortosa, C.L.; Sanchez-Rovira, P.; Ramirez-Tortosa, M.C. Hydroxytyrosol: From laboratory investigations to future clinical trials. Nutr. Rev. 2010, 68, 191-206. [CrossRef]

27. Bernini, R.; Gilardini Montani, M.S.; Merendino, N.; Romani, A.; Velotti, F. Hydroxytyrosol-Derived Compounds: A Basis for the Creation of New Pharmacological Agents for Cancer Prevention and Therapy. J. Med. Chem. 2015, 58, 9089-9107. [CrossRef]

28. Floris, B.; Galloni, P.; Conte, V.; Sabuzi, F. Tailored functionalization of natural phenols to improve biological activity. Biomolecules 2021, 11, 1325. [CrossRef]

29. Monteiro, M.; Silva, A.F.R.; Resende, D.; Braga, S.S.; Coimbra, M.A.; Silva, A.M.S.; Cardoso, S.M. Strategies to broaden the applications of olive biophenols oleuropein and hydroxytyrosol in food products. Antioxidants 2021, 10, 444. [CrossRef]

30. Tassano, E.; Alama, A.; Basso, A.; Dondo, G.; Galatini, A.; Riva, R.; Banfi, L. Conjugation of Hydroxytyrosol with Other Natural Phenolic Fragments: From Waste to Antioxidants and Antitumour Compounds. Eur. J. Org. Chem. 2015, 2015, 6710-6726. [CrossRef]

31. Guo, Y.; Zheng, C.; Xu, W.; Si, Y.; Dou, S.; Yang, Y. Free radical scavenging and hepatoprotective effects of salidroside analogs on $\mathrm{CCl}_{4}$-induced cytotoxicity in LO2 cells. Med. Chem. Res. 2013, 22, 2524-2530. [CrossRef]

32. Horvathova, E.; Mastihubova, M.; Karnisova Potocka, E.; Kis, P.; Galova, E.; Sevcovicova, A.; Klapakova, M.; Hunakova, L.; Mastihuba, V. Comparative study of relationship between structure of phenylethanoid glycopyranosides and their activities using cell-free assays and human cells cultured in vitro. Toxicol. Vitr. 2019, 61, 104646. [CrossRef]

33. Kis, P.; Mastihubová, M. A sustainable approach to phenylethanoid glycopyranosides: Study of glycosylations promoted by zinc salts. Sustain. Chem. Pharm. 2021, 24, 100537. [CrossRef]

34. Mulani, S.K.; Guh, J.H.; Mong, K.K.T. A general synthetic strategy and the anti-proliferation properties on prostate cancer cell lines for natural phenylethanoid glycosides. Org. Biomol. Chem. 2014, 12, 2926-2937. [CrossRef]

35. Shu, P.; Zhang, L.; Liu, A.; Li, J.; Liu, Q.; Sun, N.; Zhang, Y.; Wei, X.; Cui, M.; Ju, Z.; et al. Six Natural Phenylethanoid Glycosides: Total Synthesis, Antioxidant and Tyrosinase Inhibitory Activities. ChemistrySelect 2020, 5, 10817-10820. [CrossRef]

36. Trincone, A.; Pagnotta, E.; Tramice, A. Enzymatic routes for the production of mono- and di-glucosylated derivatives of hydroxytyrosol. Bioresour. Technol. 2012, 115, 79-83. [CrossRef] 
37. Nieto-Domínguez, M.; De Eugenio, L.I.; Peñalver, P.; Belmonte-Reche, E.; Morales, J.C.; Poveda, A.; Jiménez-Barbero, J.; Prieto, A.; Plou, F.J.; Martínez, M.J. Enzymatic Synthesis of a Novel Neuroprotective Hydroxytyrosyl Glycoside. J. Agric. Food Chem. 2017, 65, 10526-10533. [CrossRef]

38. Potocká, E.; Mastihubová, M.; Mastihuba, V. Enzymatic synthesis of tyrosol glycosides. J. Mol. Catal. B Enzym. 2015, 113, 23-28. [CrossRef]

39. Karnišová Potocká, E.; Mastihubová, M.; Mastihuba, V. Enzymatic synthesis of tyrosol and hydroxytyrosol $\beta$-D-fructofuranosides. Biocatal. Biotransform. 2019, 37, 18-24. [CrossRef]

40. Karnišová Potocká, E.; Mastihubová, M.; Mastihuba, V. Transrutinosylation of tyrosol by flower buds of Sophora japonica. Food Chem. 2021, 336, 127674. [CrossRef]

41. Hollá, V.; Hill, R.; Antošová, M.; Polakovič, M. Design of immobilized biocatalyst and optimal conditions for tyrosol $\beta$-galactoside production. Bioprocess Biosyst. Eng. 2021, 44, 93-101. [CrossRef]

42. Hollá, V.; Karkeszová, K.; Antošová, M.; Polakovič, M. Transglycosylation properties of a Kluyveromyces lactis enzyme preparation: Production of tyrosol $\beta$-fructoside using free and immobilized enzyme. Process Biochem. 2021, 110, 168-175. [CrossRef]

43. Míguez, N.; Ramírez-Escudero, M.; Gimeno-Pérez, M.; Poveda, A.; Jiménez-Barbero, J.; Ballesteros, A.O.; Fernández-Lobato, M.; Sanz-Aparicio, J.; Plou, F.J. Fructosylation of Hydroxytyrosol by the $\beta$-Fructofuranosidase from Xanthophyllomyces dendrorhous: Insights into the Molecular Basis of the Enzyme Specificity. ChemCatChem 2018, 10, 4892-4901. [CrossRef]

44. Khymenets, O.; Joglar, J.; Clapés, P.; Parella, T.; Covas, M.I.; De La Torre, R. Biocatalyzed synthesis and structural characterization of monoglucuronides of hydroxytyrosol, tyrosol, homovanillic alcohol, and 3-(4'-hydroxyphenyl) propanol. Adv. Synth. Catal. 2006, 348, 2155-2162. [CrossRef]

45. Bassanini, I.; Krejzová, J.; Panzeri, W.; Monti, D.; Křen, V.; Riva, S. A Sustainable One-Pot, Two-Enzyme Synthesis of Naturally Occurring Arylalkyl Glucosides. ChemSusChem 2017, 10, 2040-2045. [CrossRef]

46. Green, J.W. The Glycofuranosides. Adv. Carbohydr. Chem. Biochem. 1967, 21, 95-142. [CrossRef]

47. Taha, H.A.; Richards, M.R.; Lowary, T.L. Conformational analysis of furanoside-containing mono- and oligosaccharides. Chem. Rev. 2013, 113, 1851-1876. [CrossRef]

48. Rahim, M.A.; Saeed, F.; Khalid, W.; Hussain, M.; Anjum, F.M. Functional and nutraceutical properties of fructo-oligosaccharides derivatives: A review. Int. J. Food Prop. 2021, 24, 1588-1602. [CrossRef]

49. Konishi, T.; Ishii, T. The Origin and Functions of Arabinofuranosyl Residues in Plant Cell Walls. Trends Glycosci. Glycotechnol. 2012, 24, 13-23. [CrossRef]

50. Pičmanová, M.; Møller, B.L. Apiose: One of nature's witty games. Glycobiology 2016, 26, 430-442. [CrossRef]

51. Peltier, P.; Euzen, R.; Daniellou, R.; Nugier-Chauvin, C.; Ferrières, V. Recent knowledge and innovations related to hexofuranosides: Structure, synthesis and applications. Carbohydr. Res. 2008, 343, 1897-1923. [CrossRef]

52. Chlubnova, I.; Legentil, L.; Dureau, R.; Pennec, A.; Almendros, M.; Daniellou, R.; Nugier-Chauvin, C.; Ferrières, V. Specific and non-specific enzymes for furanosyl-containing conjugates: Biosynthesis, metabolism, and chemo-enzymatic synthesis. Carbohydr. Res. 2012, 356, 44-61. [CrossRef]

53. Dumon, C.; Song, L.; Bozonnet, S.; Fauré, R.; O’Donohue, M.J. Progress and future prospects for pentose-specific biocatalysts in biorefining. Process Biochem. 2012, 47,346-357. [CrossRef]

54. Numan, M.T.; Bhosle, N.B. $\alpha$-L-arabinofuranosidases: The potential applications in biotechnology. J. Ind. Microbiol. Biotechnol. 2006, 33, 247-260. [CrossRef]

55. Manoochehri, H.; Hosseini, N.F.; Saidijam, M.; Taheri, M.; Rezaee, H.; Nouri, F. A review on invertase: Its potentials and applications. Biocatal. Agric. Biotechnol. 2020, 25, 101599. [CrossRef]

56. Karnišová Potocká, E.; Mastihubová, M.; Mastihuba, V. Apiose-relevant glycosidases. Catalysts 2021, 11, 1251. [CrossRef]

57. Kaur, A.P.; Bhardwaj, S.; Dhanjal, D.S.; Nepovimova, E.; Cruz-Martins, N.; Kuča, K.; Chopra, C.; Singh, R.; Kumar, H.; Sen, F.; et al. Plant prebiotics and their role in the amelioration of diseases. Biomolecules 2021, 11, 440. [CrossRef]

58. Torres-Mendoza, D.; González, J.; Ortega-Barría, E.; Heller, M.V.; Capson, T.L.; McPhail, K.; Gerwick, W.H.; Cubilla-Rios, L. Weakly Antimalarial Flavonol Arabinofuranosides from Calycolpus warszewiczianus. J. Nat. Prod. 2006, 69, 826-828. [CrossRef]

59. Park, Y.J.; Kim, D.M.; Jeong, M.H.; Yu, J.S.; So, H.M.; Bang, I.J.; Kim, H.R.; Kwon, S.H.; Kim, K.H.; Chung, K.H. (-)-Catechin-7O- $\beta$-D-Apiofuranoside Inhibits Hepatic Stellate Cell Activation by Suppressing the STAT3 Signaling Pathway. Cells $2019,9,30$. [CrossRef]

60. Mastihubová, M.; Poláková, M. A selective and mild glycosylation method of natural phenolic alcohols. Beilstein J. Org. Chem. 2016, 12, 524-530. [CrossRef]

61. Dudíková, J.; Mastihubová, M.; Mastihuba, V.; Kolarova, N. Exploration of transfructosylation activity in cell walls from Cryptococcus laurentii for production of functionalised $\beta$-D-fructofuranosides. J. Mol. Catal. B Enzym. 2007, 45, 27-33. [CrossRef]

62. Kis, P.; Potocká, E.; Mastihuba, V.; Mastihubová, M. Efficient chemoenzymatic synthesis of 4-nitrophenyl $\beta$-D-apiofuranoside and its use in screening of $\beta$-D-apiofuranosidases. Carbohydr. Res. 2016, 430, 48-53. [CrossRef] [PubMed]

63. Mastihuba, V.; Karnišová Potocká, E.; Uhliariková, I.; Kis, P.; Kozmon, S.; Mastihubová, M. Reaction mechanism of $\beta$-apiosidase from Aspergillus aculeatus. Food Chem. 2019, 274, 543-546. [CrossRef]

64. Imamura, A.; Lowary, T. Chemical Synthesis of Furanose Glycosides. Trends Glycosci. Glycotechnol. 2011, 23, 134-152. [CrossRef]

65. Gallo-Rodriguez, C.; Kashiwagi, G.A. Selective Glycosylations with Furanosides. In Selective Glycosylation: Synthetic Methods and Catalysts; Bennett, C.S., Ed.; Wiley-VCH Verlag GmbH \& Co. KGaA: Weinheim, Germany, 2017; pp. 297-326. ISBN 9783527696239. 
66. Backinowsky, L.V.; Nepogod'ev, S.A.; Shashkov, A.S.; Kochetkov, N.K. 1,2-O-cyanoalkylidene derivatives of furanoses as 1,2-trans-glycosylating agents. Carbohydr. Res. 1985, 138, 41-54. [CrossRef]

67. Ho, P.-T. Branched-chain sugars. Reaction of furanoses with formaldehyde: A simple synthesis of D- and L-apiose. Can. J. Chem. 1979, 57, 381-383. [CrossRef]

68. Hammerschmidt, F.; Öhler, E.; Polsterer, J.-P.; Zbiral, E.; Balzarini, J.; Declercq, E. Ein einfacher Weg zu D-Apio- $\beta$-D-furanosylund 2'-Desoxyapio- $\beta$-D-furanosylnucleosiden. Liebigs Ann. 1995, 1995, 551-558. [CrossRef]

69. Kam, B.L.; Barascut, J.-L.; Imbach, J.-L. A general method of synthesis and isolation, and an n.m.r-spectroscopic study, of tetra-O-acetyl-D-aldopentofuranoses. Carbohydr. Res. 1979, 69, 135-142. [CrossRef]

70. Gravier-Pelletier, C.; Ginisty, M.; Le Merrer, Y. A versatile scaffold for a library of liposidomycins analogues: A crucial and potent glycosylation step. Tetrahedron Asymmetry 2004, 15, 189-193. [CrossRef]

71. Mosmann, T. Rapid colorimetric assay for cellular growth and survival: Application to proliferation and cytotoxicity assays. J. Immunol. Methods 1983, 65, 55-63. [CrossRef]

72. Fotakis, G.; Timbrell, J.A. In vitro cytotoxicity assays: Comparison of LDH, neutral red, MTT and protein assay in hepatoma cell lines following exposure to cadmium chloride. Toxicol. Lett. 2006, 160, 171-177. [CrossRef]

73. Tutino, V.; Caruso, M.G.; Messa, C.; Perri, E.; Notarnicola, M. Antiproliferative, antioxidant and anti-inflammatory effects of hydroxytyrosol on human hepatoma HepG2 and Hep3B cell lines. Anticancer Res. 2012, 32, 5371-5377.

74. Kuwajima, H.; Takai, Y.; Takaishi, K.; Inoue, K. Synthesis of ${ }^{13}$ C-Labeled Possible Intermediates in the Biosynthesis of Phenylethanoid Derivatives, Cornoside and Rengyosides. Chem. Pharm. Bull. 1998, 46, 581-586. [CrossRef]

75. Yen, G.C.; Chen, H.Y. Antioxidant Activity of Various Tea Extracts in Relation to Their Antimutagenicity. J. Agric. Food Chem. 1995, 43, 27-32. [CrossRef]

76. Zhao, J.; Liu, T.; Ma, L.; Yan, M.; Gu, Z.; Huang, Y.; Xu, F.; Zhao, Y. Antioxidant and preventive effects of extract from Nymphaea candida flower on in vitro immunological liver injury of rat primary hepatocyte cultures. Evid. Based Complement. Altern. Med. 2011, 2011, 497673. [CrossRef]

77. Sharma, O.P.; Bhat, T.K. DPPH antioxidant assay revisited. Food Chem. 2009, 113, 1202-1205. [CrossRef]

78. Čipák, L.; Miadoková, E.; Dingová, H.; Kogan, G.; Novotný, L.; Rauko, P. Comparative DNA protectivity and antimutagenicity studies using DNA-topology and Ames assays. Toxicol. Vitr. 2001, 15, 677-681. [CrossRef]

79. Majer, B.J.; Mersch-Sundermann, V.; Darroudi, F.; Laky, B.; de Wit, K.; Knasmüller, S. Genotoxic effects of dietary and lifestyle related carcinogens in human derived hepatoma (HepG2, Hep3B) cells. Mutat. Res. 2004, 551, 153-166. [CrossRef]

80. Singh, N.P.; McCoy, M.T.; Tice, R.R.; Schneider, E.L. A simple technique for quantitation of low levels of DNA damage in individual cells. Exp. Cell Res. 1988, 175, 184-191. [CrossRef] 